\section{幽闹 Digital Commons@}

Loyola Marymount University

LMU Loyola Law School
Loyola of Los Angeles International and Comparative Law Review

Summer 8-10-2021

\title{
Grounding Suicide Terrorism in Death Anxiety and Consumer Capitalism
}

James M. Donovan

University of Kentucky's J. David Rosenberg College of Law

Follow this and additional works at: https://digitalcommons.Imu.edu/ilr

Part of the Other Sociology Commons

\section{Recommended Citation}

James M. Donovan, Grounding Suicide Terrorism in Death Anxiety and Consumer Capitalism, 44 Loy. L.A. Int'l \& Comp. L. Rev. 1 (2021).

Available at: https://digitalcommons.Imu.edu/ilr/vol44/iss1/1

This Article is brought to you for free and open access by the Law Reviews at Digital Commons @ Loyola Marymount University and Loyola Law School. It has been accepted for inclusion in Loyola of Los Angeles International and Comparative Law Review by an authorized administrator of Digital Commons@Loyola Marymount University and Loyola Law School. For more information, please contact digitalcommons@lmu.edu. 


\title{
Grounding Suicide Terrorism in Death Anxiety and Consumer Capitalism
}

\author{
JAMES M. DONOVAN*
}

Perhaps the whole root of our trouble, the human trouble, is that we will sacrifice all the beauty of our lives, will imprison ourselves in totems, taboos, crosses, blood sacrifices, steeples, mosques, races, armies, flags, nations, in order to deny the fact of death, which is the only fact we have. ${ }^{1}$

\section{INTRODUCTION}

Thomas Huxley is known to history as "Darwin's Bulldog" for his forceful advocacy of Charles Darwin's theory of evolution. ${ }^{2}$ As part of that debate, he is claimed to have once remarked that "we must learn what is true in order to do what is right." ${ }^{3}$ Whether speaking about physical or social processes, our understanding is enhanced when we know how the pieces fit together.

Suicide terrorism is one topic about which we would like to do the right thing. For most, that would include finding a way to prevent suicide terrorist attacks. To the extent that prevention depends on removing the motivations that exist for those who engage in the activity, it can be difficult to learn what actually drives individuals to engage in suicide terrorism, particularly because the perpetrators are inevitably unavailable to tell us their reasons. As a result, decision-makers often fall back on

\footnotetext{
* James M. Donovan (J.D. Loyola New Orleans 2003; Ph.D. Tulane University 1994; B.A. University of Tennessee at Chattanooga 1981) is Director and James and Mary Lassiter Associate Professor of Law at the University of Kentucky's J. David Rosenberg College of Law. A previous draft of this paper benefited from roundtable discussion at the Secção de Sociologia do Direito e da Justiça da Associação Portuguesa de Sociologia [Annual Meeting of the Research Committee on Sociology of Law] [RCSL/SDJ] that took place in Lisbon, Portugal from September 12-13, 2018.

1. James BALdwin, The Fire NeXT Time 91 (Michael Joseph Ltd. 5th ed. 1968) (1963).

2. But see John van Wyhe, Why There Was No 'Darwin's Bulldog': Thomas Henry Huxley's Famous Nickname, 35 LinNEAN 26 (2019), https://www.ca1-tls.edcdn.com/Linnean_Vol-35_1_ April-2019_Web.pdf?mtime $=20190624175025.5$.

3. Charles J. LumSden \& EdWARd O. Wilson, Promethean Fire: Reflections on THE ORIGIN OF MIND vi (Harvard Univ. Press ed. 1983).
} 
assumptions and stereotypes that serve other purposes, but which rarely lead to useful or truthful insights on the problem.

This article examines an influential theory on suicide attacker motivations, the Significance Quest Theory, and suggests that this death anxiety approach can be improved by shifting its focus toward the related, but more comprehensive, Terror Management Theory. The theoretical productivity of this realignment is tested by examining the relationship between suicide attacks and one of the variables thought to trigger the underlying anxieties: the local pressures from global consumer capitalism. After describing the relationship between death anxiety and suicide terrorism generally, this article concludes by applying these insights to the ethnographic context of Egypt.

\section{WHAT WE MEAN BY "TERRORISM"}

The first step toward finding what is true regarding any subject is to identify what one intends to speak about. Definitions are not themselves true or false statements, but rather, are only more or less useful. They are necessary to collect instances of the same kind from which the truth can then be discerned. Accordingly, referents for important terms should be plainly described to eliminate ad hoc ambiguities that muddy the path toward a meaningful and helpful conclusion.

Even a casual survey of instances of the use of terrorism shows that it is a contested category, often used as a ready-at-hand accusation applied to any disruptive activity disfavored by those in power. ${ }^{4}$ Oil company executives, for example, have attempted to score points by labeling

4. See Michael Loadenthal, Othering Terrorism: A Rhetorical Strategy of Strategic Labeling, 13 Genocide Stud. \& Prevention: An InT'L J. 74, 95 (2019). See also Alex Schmid \& A.J. Jongman, Political Terrorism: A New Guide to ACtors, Authors, ConcePts, Data BASES, THEORIES, AND LiTERATURE 5-6 (1988) (analyzing 109 different definitions of "terrorism”). Schmid \& Jongman use their study to construct the following thorough definition:

Terrorism is an anxiety-inspiring method of repeated violent action, employed by (semi-) clandestine individual, group, or state actors, for idiosyncratic, criminal, or political reasons, whereby - in contrast to assassination - the direct targets of violence are not the main targets. The immediate human victims of violence are generally chosen randomly (targets of opportunity) or selectively (representative or symbolic targets) from a target population, and serve as message generators. Threat- and violencebased communication processes between terrorists (organization), (imperiled) victims, and main targets are used to manipulate the main target (audience(s)), turning it into a target of terror, a target of demands, or a target of attention, depending on whether intimidation, coercion, or propaganda is primarily sought.

Id. at 28 . 
pipeline protestors as "terrorists," and a recent effort to make the Georgia state code available for free online has been characterized as a "strategy of terrorism" by the State. ${ }^{6}$ The "terrorist" label serves as the modern analogy to epithets of communist in the 1950s, or witch from long ago, in that they all share the quality of lacking firm content other than to categorize the target as deserving per se condemnation.

Formal settings fare little better. The UN Security Council has identified specific acts as terrorism while avoiding a general definition. ${ }^{7} \mathrm{Re}-$ gional instruments have erred in the opposite direction by offering "more than one hundred different proposed definitions of terrorism" between 1936 and $1981 .^{8}$ The diversity of those outcomes, however, has frustrated the effort to carve out a universally recognized customary international crime. ${ }^{9}$

The present discussion favors restricting the category of terrorism to acts which seek to provoke a change of policy by inflicting violence or the threat of violence upon innocent civilians, rather than directly targeting the policymakers responsible for the contested circumstances, or their agents. ${ }^{10}$ Without the criterion of targeting innocent proxies, terrorism becomes functionally indistinguishable from routine military conflicts. One strategic assumption is presumably that threatened civilians will exert pressure on authorities to meet the demands of the assailants. Alternatively, or, in systems where civilians lack any direct political authority over the government, there is an assumption that the authorities have either compassion for their citizens, or fear of negative judgments on the international stage sufficient to change their course.

This definition differs from some by requiring what other definitions may permit, namely, that the hallmark of terrorism is the targeting of the morally innocent in order to provoke a change from a third party. ${ }^{11}$ For example, Per Bauhn argues that sacrificing the morally innocent to

5. Valerie Richardson, Dakota Access Pipeline Executive Compares Lawless Protestors to Terrorists, WASH. TIMES (Feb. 15, 2017), http://www.washingtontimes.com/news/2017/feb/15/dakota-access-exec-compares-protesters-terrorists/.

6. Adam Liptak, Accused of 'Terrorism' for Putting Legal Materials Online, N.Y. TIMES (May 13, 2019), https://www.nytimes.com/2019/05/13/us/politics/georgia-official-code-copyright. html.

7. Ben SAUl, DEFINING TERRORISM IN INTERNATIONAL LAW 319 (2006).

8. JEFFREY D. SIMON, LONE WOLF TERRORISM: UNDERSTANDING THE GROWING THREAT 259 (2013).

9. SAUL, supra note 7 , at 318 .

10. C.A.J. Coady, The Morality of Terrorism, 60 PHIL. 47, 52 (1985).

11. See Andrew H. Kydd \& Barbara F. Walter, The Strategies of Terrorism, 31 INT'L SEC. 49, 51 (2006) (terming this the "attrition" goal of terrorism amongst the other identified goals of intimidation, provocation, spoiling, and outbidding). 
intimidate others may be "a feature of some political terrorist acts, [but not] all of them." 12 Other offerings concede the targeting of noncombatants as part of the definition, but expand this term to also encompass government officials who direct combat and military individuals who are not actively engaged in combat at the moment of the terrorist attack. ${ }^{13}$ These inclusions may satisfy a requirement of targeting technical noncombatants in the sense that they are not actively firing weapons at the moment of the attack. However, these inclusions arguably violate the spirit of the broader definition by protecting those who have the power to offer the demanded concessions or who have an ongoing history of enforcing the challenged rules, and in any event are not "innocent" in the same sense as ordinary civilians.

Another way this definition varies from others is that it does not categorically exclude states from the list of those who can commit acts of terrorism. ${ }^{14}$ Although most states hold that only non-state actors can be considered terrorists, ${ }^{15}$ this rhetoric can be seen as an attempt to portray one's own actions as legitimate military exercises, while construing the actions of others as potentially illegitimate war crimes. The inconsistency of this posture is quickly exposed by the ease with which states accuse one another of terrorism. ${ }^{16}$ A state may even go so far as to baldly propose plans that plainly cross the line into terrorism. For example, President Trump called to attack jihadist leaders by "taking out their families."17 President Trump later threatened to target Iranian sites of cultural

12. Per Bauhn, Ethical Aspects of Political Terrorism: The Sacrificing of the INNOCENT 74 (1989).

13. Max Abrahms, Why Terrorism Does Not Work, 31 INT'L SEC. 42, 52 (2006) (including military targets in his analysis to find that "[g]roups whose attacks on civilian targets outnumbered attacks on military targets systematically failed to achieve their policy objectives.").

14. Kydd and Walter strike a balance by, on the one hand, "not focus[ing] on state terrorism because states face very different opportunities and constraints in their use of violence, and [because] the two cases are [not] similar enough to be profitably analyzed together," while on the other hand, defining terrorism in such a way that state terrorism is not necessarily precluded. Kydd \& Walter, supra note 11 , at 52 .

15. Alex P. SCHMid, Routledge Handbook of Terrorism ReSEARCH 48 (2011).

16. See Elaine Sciolino, U.S. Accuses Benin of Abetting Libyan Terrorism, N.Y. TIMES, May 20, 1988. See also Fred Pleitgen, Iranian Foreign Minister Accuses US of 'State Terrorism' as Country's Parliament Votes to Designate US Forces as 'Terrorists' (Jan. 7, 2020, 4:08 AM), https://www.cnn.com/2020/01/07/middleeast/iran-zarif-united-states-intl/index.html.

17. John Fund, Trump's Call to Kill Family Members of Terrorists is Quarter-Baked, NAT'L REV. (Dec. 18, 2015, 9:00 AM), http://www.nationalreview.com/article/428719/kill-terroristsfamilies-gangsta-trump. 
heritage, ${ }^{18}$ an act which would constitute a war crime, ${ }^{19}$ but would also be terroristic because civilians were the intended casualties. If attacking noncombatants to coerce military targets is the core criterion that defines terrorism, proposing this strategy as state policy would qualify as "state terrorism." Despite the clear possibility of terrorist intentions by some state actors, the majority of data on terrorism typically excludes state-authorized engagements that target noncombatants, perhaps placing them under the category of "collateral damage."

The stricter standard for "noncombatant" offered here has been defended elsewhere. ${ }^{20}$ Even if the available data is not consistently sorted to this level of detail, the present definition reliably identifies acts that satisfy the key elements, allowing for a consistent comparison of events in order to isolate helpful relationships and trends. Under this definition, political assassinations or targeting soldiers-for example, the bombing of the USS Cole - are at best crimes, but not terrorism. U.S. prosecutors correctly declined to charge the Fort Hood shooter as a terrorist because he had made deliberate efforts to target soldiers and avoid civilians. ${ }^{21}$

Similarly, under this standard, it is difficult to argue that the 1985 Oklahoma City bombing, which targeted a government building but incurred substantial collateral civilian casualties, was an act of terrorism. The perpetrator, Timothy McVeigh claimed that he "did not know there was a daycare center inside the building," and that, had he known, it might have given him pause to switch targets because "that's a large amount of collateral damage." ${ }^{22}$ It would be harder still to argue that the bombing constituted an act of terrorism while also maintaining that the United States' use of drones to kill military targets in civilian settings is not. ${ }^{23}$ Neither is probably terrorism in the strict sense since civilians were not the primary targets.

18. Martin Chulov et al., Trump Vows to Hit 52 Sites 'Very Hard' if Iran Retaliates Over Suleimani Killing, THE GUARDIAN (Jan. 5, 2020, 5:11 AM), https://www.theguardian.com/world /2020/jan/05/donald-trump-vows-to-hit-52-sites-very-hard-if-iran-retaliates-for-suleimani-killing.

19. See Prosecutor v. Al Mahdi, Case No. ICC-01/12-01/15, Judgment and Sentence (Sept. 27, 2016), https://www.icc-cpi.int/courtrecords/cr2016_07244.pdf. See also Hague Convention of 1907, annex, art. 27, Oct. 18, 1907, 36 Stat. 2277.

20. James A. Donovan, Civilian Immunity and the Rebuttable Presumption of Innocence, $5 \mathrm{~J}$. L. SOC'Y 409, 450-54 (2004).

21. Peter Bergen, United States of Jihad: Who Are America's Homegrown TERRORISTS AND HOW DO WE STOP THEM? 84 (2016).

22. SIMON, supra note 8 , at 48 .

23. Some may argue that McVeigh was an independent actor, and thus only his acts were terrorism. State actions are sometimes stipulated as necessarily falling outside the criteria that signal an event as terrorism. The justification for this exclusion may be because state misdeeds are already liable under existing rules against war crimes and human rights violations. See Press Release, Security Council, Addressing Security Council, Secretary-General Calls on Counter- 


\section{What We MEAN BY "SUICIDE TERRORISM"}

Assuming that we have a solid grasp of what it means for an act to be terrorism, we may believe that the elements of the subset suicide terrorism become immediately clear: Suicide terrorism is a form of terrorism by which the attackers must kill themselves in order for the attack on innocent noncombatants to be successful. Common instances include detonating a bomb in a shopping center or steering a car into a sidewalk café. It is not the death itself, but the perpetrator's intent to die that serves as the hallmark of suicide terrorism. Many terrorists are killed during attacks (e.g., the 2002 Moscow theatre hostage crisis by Chechen separatists ${ }^{24}$ ), but their deaths are not always an essential element of the plan, only collateral consequences of its execution. The literature therefore recognizes a distinction between true suicide terrorism, and what has been termed "Mumbai Style" attacks in which the terrorists' deaths may have been the most likely foreseeable outcome of the plot but which remain an outcome the attackers will seek to avoid as long as possible, or even completely. ${ }^{25}$

The "why" of suicide terrorism has often been claimed to be that the strategy is more effective than general terrorism. ${ }^{26}$ Because detonation can be timed for optimal impact, one report found that each suicide attack averaged 9.28 deaths as compared to the 1.92 deaths from general terrorist attacks. ${ }^{27} \mathrm{~A}$ similar gap exists on the question of whether suicide terrorism is more effective at achieving the intended strategic objectives: Pape concludes that suicide terrorism is "associated with gains for the

Terrorism Committee to Develop Long-Term Strategy to Defeat Terror, U.N. Press Release SC/7276 (Jan. 18, 2002) (quoting Jeremy Greenstock, Committee Chairman: "Concerning State terrorism, the Committee had taken the trouble to proceed by consensus and keep subjectivism to a minimum, he said. Resolution 1373 (2001) was the primary guide for the Committee, but the Committee was also conscious of the 12 international Conventions on the subject, and none of them referred to State terrorism, which was not an international legal concept. If States abused their power, they should be judged against international conventions dealing with war crimes, international human rights and international humanitarian law."). The present discussion does not recognize a meaningful distinction between state and non-state actors as a criterion to decide whether an attack is or is not terrorism. Although some statements from then-UN Secretary-General Kofi Annan appear to favor excluding states from charges of terrorism, at other times he arguably favors the position offered here, that "any deliberate attack on innocent civilians, regardless of one's cause, is unacceptable and fits into the definition of terrorism". See also Press Conference with Foreign Minister Kamal Kharrazi (unofficial transcript) (Jan. 26, 2002),https://www.un.org/sg/en/content/sg/press-encounter/2002-01-26/press-conference-foreign-minister-kamal-kharrazi-unofficial.

24. Richard Pilch \& Adam Dolnik, The Moscow Theatre Hostage Crisis: The Perpetrators, Their Tactics, and the Russian Response, 8 INT'L NEGOT. 577, 582 (2003).

25. Mark Dechesne \& Bryn Brandt-Law, Suicide Terrorism, in HANDBOOK OF SUICIDAL BEHAVIOUR 139, 141 (Updesh Kumar ed., 2017).

26. See Diego Muro, When Does Terrorism Work? (2019) (describing a general treatment on the effectiveness of terrorism).

27. Dechesne \& Brandt-Law, supra note 25, at 150. 
terrorists' political cause about half the time, ${ }^{, 28}$ while general terrorism is reported to attain only a seven percent success rate. ${ }^{29}$ More detailed research, however, has concluded that suicides "appear to present little to no advantages over non-suicide attacks, especially given the significant costs associated with them." ${ }^{30}$ According to Kydd and Walter, the range of likely effectiveness is narrow and the attritional suicide bombings appear to be effective only against democracies because they are "more constrained in their ability to retaliate," and are more likely to capitulate to demands than authoritarian societies. ${ }^{31}$ Given such limited and uncertain outcomes, the full tally of costs is likely to exceed rational benefits. Less obvious motivations than body counts should therefore be considered when deliberating the cause of suicide terrorism.

The conceptual problem arises in that, while most persons would abhor the use of civilian casualties to advance political goals, such actions are not beyond the ken of the ordinary observer. Terrorists may be crude criminals, but we nonetheless can understand what goes through their minds as they plot their heinous strategies. Their own deaths are a likely, but possibly avoidable, outcome. The true suicide terrorist, though, because he intends and may even want to die, arguably exceeds our imaginative empathy. ${ }^{32}$

What unsettles observers about suicide terrorism centers not on the willingness to sacrifice innocents to advance political objectives-ordinary warfare does as much, as the carpet bombing of Dresden and the atomic bombings of Hiroshima and Nagasaki demonstrated - but rather on the reported eagerness with which such assignments of self-annihilation are often sought and executed. Many suicide terrorists are said to be so excited by the idea that they seek out organizations promising the best opportunities. ${ }^{33}$ The hope of becoming an honored martyr surpasses loyalty to a cause or group. Because "his sense of security is derived from his passionate attachment and not from the excellence of his cause," 34

28. Robert A. Pape, Dying to Win: The Strategic logic of Suicide Terrorism 64 (2005).

29. Abrahms, supra note 13 , at 51 .

30. Joseph Mroszczyk, Dying for a Reason: An Empirical Assessment of the Tactical Utility of Suicide Operations (2018), (Ph.D. dissertation, Northeastern University) (on file with Northeastern University).

31. Kydd \& Walter, supra note 11 , at 61 .

32. Emad E. Aysha, Islamist Suicide Terrorism and Erich Fromm's Social Psychology of Modern Times, 5 J. SOC. \& POL. PSYCH. 82, 82-83 (2017).

33. ARIEL MERARI, Driven to DEATH: PSYCHOlOGICAL AND SOCIAL ASPECTS OF SUICIDE TERRORISM 121 (2010).

34. ERIC HofFer, The True Believer: ThOughts on the NATURe OF MASS MOVEMENTS 85 (Harper Perennial Mod. Classics reissued ed. 2010) (1951). 
being "a fighter for the cause becomes more important than the cause itself." " 35 The idea of someone lacking even the wish or hope to live and instead rushing headlong to extinguish themselves in furtherance of a sometimes lightly-held cause is uniquely disturbing because most of us strive to survive. Our discomfort often leads us to dismiss the actor as crazy or mentally ill.

Partisans of military conflicts are not typically known for a serious interest in what motivates opponents. The natural default is to depict the enemy as unreasonable, unnatural, certainly evil, or even arguably subhuman. ${ }^{36}$ Terrorists may be characterized in even harsher terms because they target innocent civilians. For example, after the September 11, 2001 suicide attacks in New York City (more commonly known as 9/11), President George W. Bush stated that the terrorists acted because "they hate our freedoms - our freedom of religion, our freedom of speech, our freedom to vote and assemble and disagree with each other." ${ }^{37}$ Although framed as a description of the terrorists' point of view, such statements are known to be inaccurate, conveying only what motivations the speakers project onto the actors. ${ }^{38}$ This depiction of terrorists offers little opportunity for a solution other than to seek their annihilation which, not coincidentally, is often the path pursued.

One advocate for the illness model concluded that suicide terrorists are "so consumed by pain, fear, crisis, and other personal problems that the opportunity costs of their suicide becomes quite affordable . . . . volunteering to carry out a suicide attack would be like raising your hand and saying, "Hi, I have serious mental health problems." 39 This glib characterization well reflects our own society's posture that suicidal tendencies are inherently unhealthy. If individuals who commit suicide are therefore necessarily ill, all the more so are suicide terrorists who wish to take others with them.

35. Jerrold M. Post, The Mind of the Terrorist: The Psychology of Terrorism FROM THE IRA TO AL-QAEDA 61 (2007).

36. Jeanne M. Woods \& James M. Donovan, “Anticipatory Self-Defense” and Other Stories, 14 KAN. J. L. \& PUB. POL’Y 487, 487 (2005).

37. George W. Bush, Former President of the United States, Address Before a Joint Session of the Congress on the United States Response to the Terrorist Attacks of September 11 (Sept. 20, 2001), in 37 WeEkly COMPILATION PRESIDENTIAL DOCUMENTS 1347, 1348, https:// www.govinfo.gov/content/pkg/WCPD-2001-09-24/pdf/WCPD-2001-09-24-Pg1347.pdf.

38. SCOTt Atran, TRENDS In Suicide Terrorism: SENSE AND NONSENSE 5 (Aug. 2004), https://www.researchgate.net/publication/268488742_trends_in_suicide_terrorism_sense_and_ nonsense/.

39. Adam Lankford, The Myth Of Martyrdom: What Really Drives Suicide Bombers, Rampage SHoOters, AND Other Self-Destructive Killers 8, 174 (2013). 
Consequently, we experience a certain resistance to the evidence that, despite our cultural predisposition, suicide terrorists are not uniquely mentally ill. In fact, among experts, the suggestion that suicide attacks are the result of mental illness has always been a minority view. First, the epidemiology of mental illness and suicidal tendencies does not track the rise and fall of suicide attacks. Nor does the theory account for the demographic skew of suicide terrorists toward the middle class, ${ }^{40}$ unless one is also prepared to suggest that persons from those backgrounds are uniquely vulnerable to psychological disfunction leading to suicide. ${ }^{41}$

More pointedly, direct evidence exists that puts the mental illness hypothesis to rest. Ariel Merari and his colleagues conducted a controlled study of the personality types of would-be suicide attackers. They found that a majority $(60 \%)$ of would-be suicides were diagnosed as dependentavoidant personality types, as opposed to only $16 \%$ of controls. ${ }^{42}$ By this, Merari means that the would-be suicide attackers possessed "a pronounced lack of self-confidence, difficulty in making decisions independently, reliance on others' opinions, reluctance to express disagreement out of fear that this may result in disapproval and rejection, and willingness to carry out unpleasant tasks to please others." ${ }^{43}$ Avoidant personalities, moreover, are characterized by "timidity and fear of criticism, of being shamed or ridiculed." 44

The illness model, though, demands more than finding a consistent personality profile, even an impressionable and compliant one. Merari offers further data that speaks directly to the mental illness hypothesis. He found that $40 \%$ of suicide bombers had suicidal tendencies, as compared to none in the control and attack organizer groups. ${ }^{45}$ This finding initially appears to support the belief that suicide attackers display signs of mental illness. However, viewing within-group comparisons undermines that simplistic conclusion. Merari reports that among those failed attackers who actually pushed the button to execute a planned attack, only $25 \%$ fit the suicidal profile, as compared to $45.5 \%$ of the eleven who did

40. MERARI, supra note 33, at 75-77. See also SCOTT ATRAn, TALKInG TO THE ENEMY: FAITH, BROTHERHOOD, AND THE (UN)MAKING OF TERRORISTS 113, 115 (2010).

41. See e.g., Sang-Uk Lee et al., Suicide Rates across Income Levels: Retrospective Cohort Data on 1 Million Participants Collected between 2003 and 2013 in South Korea, 27 J. EPIDEMIOLOGY 258, 258 (2017) (arguing that risk for suicide increases as socioeconomic status falls).

42. MERARI, supra note 33, at 112.

43. Id.

44. Id.

45. Ariel Merari et al., Personality Characteristics of "Self-Martyrs"/"Suicide Bombers" and Organizers of Suicide Attacks, 22 TERRORISM AND POL. ViOLENCE 87, 95 (2009). 
not attempt to activate the device. ${ }^{46}$ Although based upon a small sample, the striking result is that the more committed an attacker was to completing the mission, the less likely he was to possess the qualities that mental illness advocates argue to be the sine qua non of the category.

If attackers are not driven by a perverse desire for self-extinction, the motivation must lie elsewhere. Raphael Israeli has suggested that because suicide bombers lack the endogenous risk factors commonly associated with suicide, social factors prove determinative. ${ }^{47}$ As Marc Sageman pointed out, "social bonds play a more important role in the emergence of the global Salafi jihad than ideology." 48 The importance of social relationships over ideology had been identified earlier when Franco Ferracuti reported that, in "terms of family background, [he] was unable to distinguish among [Italian youths] those who became political activists, those who became terrorists, those who joined a youth gang, and those who entered the drug culture. The main determinant was who one's friends were." ${ }^{\prime 49}$

This dynamic has been more recently highlighted by Scott Atran's work among terrorist networks. "The Hamburg group [behind the 9/11 attacks] wasn't recruited or brainwashed. Like most Jihadi groups, it selfradicalized and then went looking for action. It was actually a fluid, constantly evolving network of friends and fellow travelers in search of making sense of their lives and the world." ${ }^{\circ 0}$ He goes on to say, "People, including terrorists, don't simply die for a cause; they die for each other, especially their friends." ${ }^{51}$ In fact, three of every four people who join jihad groups "do so with friends." 52

The suggestion that suicide terrorists are driven by their ties to a network of intimate relationships offers a starting point to consider more deeply what moves them to such extreme and personally destructive actions.

46. MERARI, supra note 33, at 142.

47. Raphael Israeli, Islamikaze and Their Significance, 9 TERrorism AND POL. VIOLENCE 96, 97, 105 (1997).

48. MARC SAGEMAn, Understanding TERror NetWORKS 178 (2004).

49. POST, supra note 35 , at 60 .

50. ATRAN, supra note 40, at 108.

51. Id. at 479. See also Julie Chernov Hwang, Why Terrorists Quit: The DiSENGAGEMENT OF INDONESIAN JiHADISTS 66 (2018).

52. Scott Atran, The Devoted Actor: Unconditional Commitment and Intractable Conflict Across Cultures, 57 CuRRENT ANTHROPOLOGY, S192, S199 (2016). 


\section{Suicide TERrorists' MotiVAtion: SignificAnce Quest THEORY}

The "Significance Quest Theory" (SQT) from Arie Kruglanski and his colleagues offers one of the literature's better developed explanatory models for terrorism. The theory builds upon initial premises we can accept as uncontroversial:

[1] "like other behaviors, terrorists' behavior is goal driven and [terrorism] constitutes the means through which individuals choose to pursue their goal"; and [2] "this self-regulatory process of goal pursuit is carried out against a backdrop of cultural meanings that determine what goals are worthy of pursuit and what means are effective and legitimate for that purpose." 53

Granting those premises, the laundry list of possible motives found in the literature for terrorism are not competing and contradictory explanations, but rather different expressions of "a more general motivational rubric, the quest for significance." 54

Although Kruglanski had first attempted to explain suicide terrorism as a kind of adolescent testosterone-fueled rebellion shaped by organizational agents, ${ }^{55}$ he later shifted to the description of death anxiety offered by Ernest Becker's The Denial of Death. Becker's insight was that our biological viability, both as a species and as individuals, depends upon adequately coping with the awareness of personal mortality which is both inevitable and stultifying. We are beings who have

a mind that soars out to speculate about atoms and infinity, who can place himself imaginatively at a point in space and contemplate bemusedly his own planet. This immense expansion, this dexterity, this ethereality, this self-consciousness gives to man literally the status of a small god in nature. . [Y] et, at the same time ... [that power of imagination reveals that] man is a worm and food for worms. ${ }^{56}$

The contradiction between the inspiration to strive and the awareness that all such striving is ultimately pointless results in a state of

53. Arie W. Kruglanski et al., Terrorism as Means to an End: How Political Violence Bestows

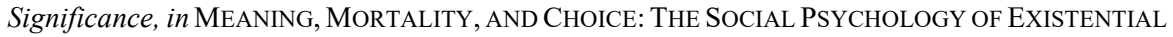
CONCERNS 203, 206-07 (Phillip R. Shaver et al. eds., 2012).

54. Id. at 207. See also Katarzyna Jasco et al., Quest for Significance and Violent Extremism: The Case of Domestic Radicalization, 38 POL. PSYCH. 815, 817-18 (2017); Michelle Dugas \& Arie W. Kruglanski, The Quest for Significance Model of Radicalization: Implications for the Management of Terrorist Detainees, 32 BEHAV. SCI. \& L. 423, 424-29 (2014).

55. Arie W. Kruglanski et al., Individual Motivations, the Group Process and Organisational Strategies in Suicide Terrorism, 3 J. POLICING, INTEL. \& COUNTER TERRORISM 70 (2008).

56. ERNEST BECKER, THE DENIAL OF DEATH 26 (1973). 
existential paralysis. To cope with this paradox, humans devise techniques to assign symbolic meaning to our objectively meaningless existence. For some, the belief in personal significance can include participation in dramatic clashes in defense of matters of cosmic importance, or deeds that will make one esteemed in the eyes of valued others. From this process, Kruglanski extracts the insight that "the underlying force to which we attribute the appeal of extreme behavior [lies in] the basic human desire to matter and have meaning in one's life." ${ }^{, 57}$ Resorting to violent, suicidal terrorist attacks are merely the actor's quest to assign significance to their existence. Considerable empirical evidence supports the predicted relationships derived from this theory. ${ }^{58}$ In the main, it works.

As SQT developed, however, this existential emphasis faded from prominence. Perhaps not coincidentally, and despite the theory's beginnings, Kruglanski eventually concedes that SQT is not uniquely tailored to the problem of suicide terrorism: "the motivations involved in suicidal and nonsuicidal types of terrorism may differ in degree rather than in kind." ${ }^{59}$ Most of his later writings focus on terrorism more broadly without offering special insight into suicide terrorism, arguably under the assumption that by shedding light on the former, we indirectly learn something about the latter.

Contrary to Kruglanski's stance on this point, other writers have concluded that general terrorism and suicide terrorism are "significantly different. ... [We] should not expect the same factors to account equally well for suicide and nonsuicide terrorism." ${ }^{60}$ Returning to Merari's comparative study, we find evidence for this nonequivalence. Would-be suicides were found to have a significantly different psychological profile from attack organizers, ${ }^{61}$ a result that appears to contradict the expectation that these persons exist on the same continuum of functional attributes.

Each position-suicide terrorism as a subtype of terrorism, and suicide terrorism as qualitatively distinct - has empirical support. The case may be that both are true, at least in their proper domains. Yet even if suicide terrorism overlaps with terrorism, there will still be a residuum of an unknown degree that cannot be accounted for by a theory such as SQT, which intends to describe what the two behaviors have in common. A

57. Arie Kruglanski et al., The Making of Violent Extremists, 22 REV. GEN. PSYCH. 107 (2018).

58. See Arie W. Kruglanski et al., The Psychology of Radicalization and Deradicalization: How Significance Quest Impacts Violent Extremism, 35 ADVANCES POL. PSYCH. 69 (2014).

59. Arie W. Kruglanski et al., Fully Committed: Suicide Bombers' Motivation and the Quest for Personal Significance, 30 POL. PSYCH. 331, 337 (2009).

60. PAPE, supra note 28 , at 9.

61. MERARI, supra note 33, at 151. 
different theory would be needed to deal with the aspect of suicide terrorism that is not subsumed within terrorism generally.

The best reading of the data, therefore, suggests that, although sharing many traits, suicide terrorists and general terrorists will diverge on only the characteristics thought to be critical to leading the former into self-extinguishing actions. Fuller explanation beyond the quest for significance would then be needed to explain the unique aspects of the suicide terrorist. An alternative candidate has placed at its heart the part of Becker's existential psychology that SQT declined to fully follow: death anxiety.

\section{Suicide Terrorists' Motivation, Revised: Terror Management THEORY}

For a variety of reasons, SQT fails to fully account for suicide terrorism. While criticisms of SQT exist, ${ }^{62}$ for present purposes, the larger obstacles can be tied to the way in which the theory develops and diverges from its original source material. As discussed below, minor adjustments of emphasis can result in significant improvements in theoretical outcomes that lead to a clearer understanding of suicide terrorism.

Becker's work gave rise to a theory, other than SQT, that built upon the same problem of death awareness. While SQT attends to the problem of meaninglessness by highlighting the immediate work to generate personal significance, Terror Management Theory (TMT) takes a more expansive view that considers in deeper detail which accomplishments will in fact be recognized as significant. ${ }^{63}$

Becker explained that knowledge of our inevitable end creates the problem of personal meaninglessness. He goes on to describe how the paradox is resolved by cultural institutions that teach us how to escape that tragic insignificance. Symbolic culture provides a shared template to negate the pitiless lessons of the physical world. Death denial can take various forms, from a belief in literal immortality via a soul-survival cult, to the extension of the self beyond our material, doomed shell to be preserved through proxies such as children, religions, group affiliations, or national allegiance. The major difference between SQT and TMT is that for TMT the substitute must be validated by the group to be effective; the

62. Mia Bloom, Chasing Butterflies and Rainbows: A Critique of Kruglanski et al. 's "Fully Committed: Suicide Bombers' Motivation and the Quest for Personal Significance," 30 POL. PSYCH. 387 (2009).

63. Mark J. Landau et al., A Function of Form: Terror Management and Structuring the Social World, 87 J. PERSONALITY \& SOC. PSYCH. 190 (2004). 
project of immortality is not a task for the private individual, contrary to what SQT suggests in its emphasis on the quest for personal significance. The result is a more comprehensive theoretical foundation for TMT:

$[\mathrm{H}]$ umans all manage the problem of knowing we are mortal by calling on two basic psychological resources. First, we need to sustain faith in our cultural worldview, which imbues our sense of reality with order, meaning, and permanence ....

But we don't just need to view life in general this way; we need to view our own life this way. The paths to literal and symbolic immortality laid out by our worldviews require us to feel that we are valuable members of our cultures. Hence, the second vital resource for managing terror is a feeling of personal significance, commonly known as self-esteem. ${ }^{64}$

While SQT can shed light on the problem of terrorism, the more complete model of TMT is required to explain suicide terrorism - one in which SQT should be seen as a special and thus, more limited case. Although overlap exists between the two theories as a result of their shared intellectual genealogy from Becker, SQT's emphasis on TMT's self-esteem prong yields a theory of terrorism that focuses on personal psychology, as it isolates the "need for closure" as the critical element leading to violent extremism. ${ }^{65}$ By contrast, while also incorporating self-esteem concerns, TMT embeds them within group institutions-making it at its core a theory of culture. Although these are nuanced distinctions, the broad claim here is that despite speaking in the same vocabulary of death anxiety, TMT and SQT focus on different explanatory facets of the same problem of suicide terrorism. While SQT may suffice to account for terrorism, of which suicide terrorism becomes a subspecies, TMT is necessary to understand the aspects of suicide terrorism that are not reducible to self-esteem. TMT is able to do this because it begins with the prior need to annul death anxiety.

Although the idea of culture built into TMT remains a challenging concept for many social scientists, ${ }^{66}$ the term references an important frame through which a wide range of existential problems can be approached. Culture offers ready-made, easily understood solutions to the

64. Sheldon Solomon et Al., The Worm at the Core: On the Role of Death in Life 9 (2015).

65. David Weber et al., The Road to Extremism: Field and Experimental Evidence that Significance Loss-Induced Need for Closure Fosters Radicalization, 114 J. PERSONALITY \& SOC. PSYCH. 270 (2018).

66. DAVid Berliner, Losing Culture: Nostalgia, Heritage, AND OUR ACCElerated TIMES 97 (Dominic Horsfall trans. 2020) ("[I]n this era of globalization and transnational movements, it is problematic to speak of cultures, in the sense of clearly outlined entities with welldefined contours, attached to a specific territory and language."). 
most common difficulties confronting a social entity mired in an existential paradox. When remedies are shared, they demand less psychological effort to maintain correct explanations of how the world works and where death-defying meaning is read.

Once internalized, these solutions become the raw material out of which personal identity is then forged. As explained in one classic ethnography,

being a Tahitian is having a "Tahitian mind," operating with assumptions and motives which have been shaped by various aspects of growing up and of everyday life in Tahitian communities. People act in a Tahitian way and "conform" to Tahitian culture because it is the natural thing for them to do. ${ }^{67}$

As with the Tahitians, so for us all. Culture tells us who we are, directs us how to behave, and teaches us what matters. To lose this basis of self-identity, and to have "slipped out of the warm embrace of a culture into the cold air of a fragmentary existence," $" 68$ can result in the disintegration of mental health. The inability to rely upon cultural resources to bolster identity is known to increase rates of suicide, ${ }^{69}$ or at least undermine the will to survive. ${ }^{70}$

Because most people will not experience the loss of their own culture, the process can be best illustrated through the way anthropologists undergo a lesser version of this break during their fieldwork. Alone in an unfamiliar environment, struggling in a foreign tongue to forge intimate bonds by assuming the role of a child who must be taught even the most simple social norms, the student "loses his sense of self-esteem and selfworth reflected back from others... 'One's concept of self disintegrates because the accustomed responses have disappeared." "71 Formerly reflexive modes of social interaction are now exhausting and intense efforts requiring the fledgling anthropologist to consciously navigate each situation. Culture shock, even in such small and relatively temporary

67. Robert I. LEVy, TAHITIANS: Mind AND EXPERIENCE IN THE SOCIETY ISLANDS 326 (1973).

68. Edward Sapir, Culture, Language and Personality: Selected Essays 97 (1966).

69. Antoon A. Leenaars et al., Genocide and Suicide Among Indigenous People: The North Meets the South, 19 CAN. J. NATIVE STUD. 337 (1999).

70. SVEn LindQVist, "EXTERminate All the Brutes": One MaN's OdysSey into the HEART OF DARKNESS AND THE ORIGINS OF EUROPEAN GENOCIDE 143 (Joan Tate trans., The New Press 1997).

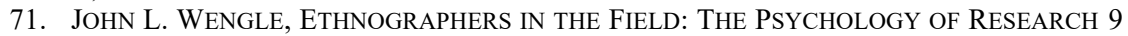
(1988) (quoting Ruth Landes). 
circumstances as these, "leans toward the view that, for the individual, the loss of his sense of identity is a symbolic death."

Given the essential role of culture in creating personality, the hypothesis offered here is that a fresh understanding of suicide terrorism will come from looking broadly at the defense of the cultural institutions that define what makes the actor feel significant. ${ }^{73}$ These norms charter the rules for symbolic immortality - the ultimate end purchased through the coin of notoriety and significance. The suicide terrorist operates, in Scott Atran's words, using a logic of appropriateness, not a logic of consequences. ${ }^{74}$ In other words, actions, even when they may make little sense in terms of the strategic objectives that are likely to be achieved or the immediate personal benefit such as renown as a martyr for the cause, can still make perfect sense under TMT when the goal is to define oneself by defending the master paradigm through which one can escape the death paradox. ${ }^{75}$ SQT operates when this more fundamental dilemma is already resolved or taken for granted.

Given the role that cultural values play in the definition of the self, TMT expects "that the mere existence of another [cultural worldview] destabilizes one's own worldview, and by doing so it reduces its bufferfunction." 76 TMT thus anticipates increased anxiety when alternative existential solutions exist side-by-side, but more so when the worldview employed to build self-esteem is under direct attack, which contributes to a "lethal cocktail that encourages violence.""7

The resulting sequelae would be unexpected by SQT. "TMT can explain the motivation behind terrorist acts, and why individuals have the propensity to inflict destruction and death upon innocent victims, simply because they do not share common religious, political, or cultural views," an action that bears no direct benefit if the goal is to increase personal significance. ${ }^{78}$ Moreover, SQT problematizes "radicalization" under the

72. Id. at 10 .

73. The assumption for this position is that suicide bombers possess higher levels of death anxiety than the general population, or even other, nonsuicidal terrorists.

74. ATRAN, supra note 40 , at 393.

75. Jeremy Ginges et al., Sacred Bounds on Rational Resolution of Violent Political Conflict, 104 PROC. NAT'L ACAD. SCI. U.S. AM. 7357, 7359 (2007).

76. Roman Prinz, Terror MANAGEMENT THEORY: What Role Do CUltural World Views Play IN THE CAUSE AND PREVENTION OF TERRORISM? 8 (2010); Sheldon Solomon et al., Pride and Prejudice: Fear of Death and Social Behavior, 9 CURRENT DIRECTIONS PSYCH. SCI. 200, 201 (2000).

77. Tom Pyszczynski et al., Righteous Violence: Killing for God, Country, Freedom and Justice, 1 BeHAV. SCI. TERRORISM \& POL. AgGression 12, 15 (2009).

78. Miliaikeala Heen et al., Terror Management, Crime, and Law, in DENYING DEATH: AN INTERDISCIPLINARY APPROACH TO TERROR MANAGEMENT THEORY 62, 66 (Lindsey A. Harvell \& Gwendelyn S. Nisbett eds., 2016). 
apparent premise that beliefs are not to be taken seriously, and that those who treat them as Tillich's "ultimate concern[s]" anced. TMT, in contrast, predicts that such convictions are at the center of everyone's personality, and that to preserve them, a person will strive to reinforce the cultural worldviews, perhaps, as Becker noted, by seeking or forcing conversions: "[P] eople try so hard to win converts for their point of view because it is more than merely an outlook on life: it is an immortality formula" ${ }^{80}$ whose validity grows when there are fewer opposing viewpoints.

From this perspective, deeds to defend one's mechanism for proxy immortality are literal acts of self-preservation, up to and including the death of the physical body which is doomed in any case. The paradoxical result, as Kruglanski has noted, is that "[T] he willingness to die in an act of suicide terrorism may be motivated by the desire to live forever," ${ }^{, 11}$ a hypothesis that has received some on-point experimental verification. ${ }^{82}$ All of the different motivations offered by other scholars to explain suicide terrorism are thereby reducible to either triggers for existential anxiety about the threats to one's cultural lifeboat or immersion in the network of relationships that signify the greater whole as a defense against perceived dangers.

\section{THE ATTACK ON LOCAL IMMORTALITY FORMULAS: FORCED CONVERSION TO GLOBAL CONSUMER CAPITALISM}

The shift from SQT to TMT may seem like a small change. However, TMT promises to be more theoretically productive because it contains explanatory power beyond what can be achieved by focusing solely on the individual's quest for personal significance. For example, TMT, but not SQT, can accommodate the finding that those with prior religious commitments were less vulnerable to "militant interpretations of Islam that allow self-bombing" than those who were "Islamic in name only," 83 because the former already have "a base philosophy which is likely to

79. Paul Tillich, The Essential Tillich: An Anthology of the Writings of Paul TILLICH 33 (1987).

80. BECKER, supra note 56, at 255.

81. KRUGLANSKI, supra note 59, at 336.

82. Clay Routledge \& Jamie Arndt, Self-Sacrifice as Self-Defence: Mortality Salience Increases Efforts to Affirm a Symbolic Immortal Self at the Expense of the Physical Self, 38 EUR. J. SOC. PSYCH. 531 (2008).

83. Khapta Akhmedova \& Anne Speckhard, A Multi-Causal Analysis of the Genesis of Suicide Terrorism: The Chechen Case, in TANGLED ROOTS: SOCIAL AND PSYCHOLOGICAL FACTORS IN THE GENESIS OF TERRORISM 324 (Jeff Victoroff ed., 2006). 
offer some psychological buffer and protection to deal with death and other serious traumatic events." 84

This Part further illustrates the productivity of TMT by examining a significant problem about which SQT has had little to say: how do we account for the historical fact that while terrorism has a long modern history, suicide attacks did not appear until the early 1980s, and when they did appear, they were very irregular across the map? Even allowing that suicide terrorism was not a feasible strategy until the development of appropriate explosives and trigger mechanisms, there remains a discrepancy. If the two forms of violence - terrorism and suicide terrorism-are expressions of the same psychological motives, we should expect the latter tactic to be utilized as soon as the tools become available, and in any place that was already experiencing terrorist attacks. Yet this expectation is not supported by historical patterns.

The National Consortium for the Study of Terrorism and Responses to Terrorism (START) maintains a database of terrorist incidents across the globe from 1970 to present. ${ }^{85}$ The criteria for inclusion is broader than discussed earlier, and does not limit or code its events for the targeting of noncombatants. However, the general thrust of the trends remains useful for present purposes. Only the time period from 1981 - the Lebanon suicide attack of that year was the "first major contemporary suicide attack" ${ }^{\prime \prime 6}$ - through 2018 is presented here. Initial consideration has been limited to eleven focal countries with some of the heaviest attacks of suicide terrorism. Table 1 reports the incidents of suicide [Sui] relative to nonsuicide [NSui] terrorism.

\begin{tabular}{|c|c|c|c|c|c|c|c|c|c|c|c|c|c|}
\hline \multicolumn{10}{|c|}{ Table 1: Annual Suicide and Non-Suicide Terrorist Attacks } \\
\hline & Egypt & \multicolumn{2}{c|}{ India } & \multicolumn{2}{c|}{ Israel } & Lebanon & \multicolumn{2}{c|}{ Nigeria } & \multicolumn{2}{c|}{ Pakistan } \\
\cline { 2 - 14 } & Nsui & Sui & Nsui & Sui & Nsui & Sui & Nsui & Sui & Nsui & Sui & Nsui & Sui \\
\hline 1981 & 9 & 0 & 16 & 0 & 36 & 0 & 80 & 1 & 0 & 0 & 4 & 0 \\
\hline 1982 & 1 & 0 & 13 & 0 & 71 & 0 & 119 & 1 & 0 & 0 & 4 & 0 \\
\hline 1983 & 0 & 0 & 47 & 0 & 31 & 0 & 230 & 4 & 3 & 0 & 9 & 0 \\
\hline 1984 & 0 & 0 & 159 & 0 & 25 & 0 & 164 & 2 & 0 & 0 & 3 & 0 \\
\hline 1985 & 2 & 0 & 39 & 0 & 19 & 1 & 80 & 15 & 0 & 0 & 2 & 0 \\
\hline 1986 & 4 & 0 & 96 & 0 & 48 & 0 & 103 & 3 & 0 & 0 & 24 & 0 \\
\hline
\end{tabular}

84. Anne Speckhard \& Khapta Akhmedova, Black Widows and Beyond: Understanding the Motivations and Life Trajectories of Chechen Female Suicide Terrorists, in FEMALE TERRORISM AND MilitanCY: AGENCY, UTILITY, AND ORGANIZATION 100, 109 (Cindy Ness ed., 2008).

85. Global Terrorism Database, https://www.start.umd.edu/gtd/ (last visited Nov. 14, 2020).

86. ATRAN, supra note 38, at 1. 


\begin{tabular}{|c|c|c|c|c|c|c|c|c|c|c|c|c|}
\hline 1987 & 7 & 0 & 166 & 0 & 23 & 0 & 92 & 2 & 0 & 0 & 60 & 0 \\
\hline 1988 & 9 & 0 & 358 & 0 & 35 & 0 & 123 & 2 & 2 & 0 & 44 & 0 \\
\hline 1989 & 7 & 0 & 324 & 0 & 86 & 1 & 141 & 0 & 0 & 0 & 45 & 0 \\
\hline 1990 & 13 & 0 & 339 & 0 & 98 & 0 & 83 & 1 & 0 & 0 & 87 & 0 \\
\hline 1991 & 10 & 0 & 338 & 1 & 64 & 0 & 91 & 0 & 3 & 0 & 150 & 0 \\
\hline 1992 & 79 & 0 & 237 & 0 & 78 & 0 & 91 & 0 & 11 & 0 & 85 & 0 \\
\hline 1993 & 49 & 1 & 42 & 0 & 21 & 1 & 36 & 1 & 0 & 0 & 8 & 0 \\
\hline 1994 & 143 & 0 & 107 & 0 & 51 & 4 & 67 & 0 & 8 & 0 & 154 & 0 \\
\hline 1995 & 102 & 0 & 179 & 0 & 11 & 2 & 38 & 0 & 1 & 0 & 664 & 2 \\
\hline 1996 & 51 & 0 & 213 & 0 & 14 & 5 & 38 & 1 & 11 & 0 & 180 & 0 \\
\hline 1997 & 22 & 0 & 193 & 0 & 11 & 2 & 45 & 1 & 20 & 0 & 206 & 0 \\
\hline 1998 & 3 & 0 & 59 & 2 & 13 & 1 & 22 & 1 & 2 & 0 & 36 & 1 \\
\hline 1999 & 1 & 0 & 111 & 1 & 6 & 2 & 41 & 1 & 18 & 0 & 39 & 0 \\
\hline 2000 & 0 & 0 & 179 & 1 & 15 & 0 & 12 & 0 & 6 & 0 & 49 & 0 \\
\hline 2001 & 0 & 0 & 228 & 6 & 54 & 25 & 5 & 0 & 5 & 0 & 53 & 0 \\
\hline 2002 & 0 & 0 & 180 & 4 & 30 & 45 & 8 & 0 & 6 & 0 & 44 & 2 \\
\hline 2003 & 0 & 0 & 193 & 3 & 20 & 18 & 5 & 0 & 9 & 0 & 26 & 3 \\
\hline 2004 & 0 & 3 & 106 & 2 & 12 & 7 & 1 & 0 & 6 & 0 & 62 & 5 \\
\hline 2005 & 0 & 2 & 143 & 3 & 38 & 5 & 17 & 0 & 9 & 0 & 72 & 5 \\
\hline 2006 & 5 & 0 & 165 & 2 & 77 & 4 & 7 & 1 & 37 & 0 & 157 & 7 \\
\hline 2007 & 0 & 0 & 146 & 3 & 52 & 1 & 17 & 1 & 61 & 0 & 202 & 58 \\
\hline 2008 & 1 & 0 & 528 & 6 & 131 & 3 & 57 & 1 & 76 & 0 & 531 & 37 \\
\hline 2009 & 2 & 0 & 671 & 1 & 36 & 0 & 14 & 0 & 42 & 0 & 620 & 47 \\
\hline 2010 & 2 & 0 & 663 & 0 & 13 & 1 & 5 & 0 & 63 & 0 & 679 & 34 \\
\hline 2011 & 16 & 2 & 645 & 0 & 50 & 1 & 10 & 0 & 171 & 4 & 969 & 43 \\
\hline 2012 & 49 & 0 & 610 & 1 & 64 & 1 & 15 & 0 & 580 & 36 & 1602 & 52 \\
\hline 2013 & 312 & 9 & 691 & 3 & 37 & 0 & 115 & 6 & 342 & 4 & 2135 & 80 \\
\hline 2014 & 349 & 5 & 859 & 1 & 293 & 0 & 191 & 13 & 674 & 40 & 2108 & 43 \\
\hline 2015 & 631 & 16 & 878 & 6 & 58 & 0 & 40 & 4 & 511 & 127 & 1213 & 30 \\
\hline 2016 & 367 & 9 & 1017 & 8 & 49 & 1 & 39 & 2 & 479 & 54 & 2016 & 31 \\
\hline 2017 & 208 & 16 & 960 & 6 & 32 & 0 & 21 & 2 & 360 & 124 & 688 & 31 \\
\hline 2018 & 53 & 6 & 888 & 2 & 63 & 0 & 7 & 0 & 645 & 60 & 480 & 25 \\
\hline Totals & 2507 & 69 & 12786 & 62 & 1865 & 131 & 2270 & 66 & 4161 & 449 & 15510 & 536 \\
\hline
\end{tabular}


Table 1 (cont.): Annual Suicide and Non-Suicide Terrorist Attacks

\begin{tabular}{|c|c|c|c|c|c|c|c|c|c|c|}
\hline & \multicolumn{2}{|c|}{ Russia } & \multicolumn{2}{|c|}{ Somalia } & \multicolumn{2}{|c|}{ Sri Lanka } & \multicolumn{2}{|c|}{ Turkey } & \multicolumn{2}{|c|}{ Yemen } \\
\hline & Nsui & Sui & Nsui & Sui & Nsui & Sui & Nsui & Sui & Nsui & Sui \\
\hline 1981 & & & 8 & 0 & 2 & 0 & 8 & 0 & 0 & 0 \\
\hline 1982 & & & 0 & 0 & 2 & 0 & 5 & 0 & 0 & 0 \\
\hline 1983 & & & 1 & 0 & 7 & 0 & 5 & 0 & 0 & 0 \\
\hline 1984 & & & 2 & 0 & 81 & 0 & 19 & 0 & 0 & 0 \\
\hline 1985 & & & 0 & 0 & 110 & 0 & 2 & 0 & 0 & 0 \\
\hline 1986 & & & 0 & 0 & 142 & 0 & 7 & 0 & 0 & 0 \\
\hline 1987 & & & 1 & 0 & 114 & 1 & 43 & 0 & 0 & 0 \\
\hline 1988 & & & 2 & 0 & 350 & 0 & 42 & 0 & 0 & 0 \\
\hline 1989 & & & 2 & 0 & 510 & 0 & 114 & 0 & 0 & 0 \\
\hline 1990 & & & 12 & 0 & 140 & 1 & 195 & 0 & 0 & 0 \\
\hline 1991 & & & 8 & 0 & 113 & 2 & 293 & 0 & 5 & 0 \\
\hline 1992 & 21 & 0 & 21 & 0 & 102 & 1 & 514 & 0 & 24 & 0 \\
\hline 1993 & 4 & 0 & 23 & 0 & 7 & 2 & 29 & 0 & 6 & 0 \\
\hline 1994 & 47 & 0 & 57 & 0 & 32 & 3 & 300 & 0 & 19 & 0 \\
\hline 1995 & 37 & 0 & 13 & 0 & 115 & 11 & 133 & 0 & 8 & 0 \\
\hline 1996 & 66 & 0 & 16 & 0 & 170 & 6 & 51 & 3 & 8 & 0 \\
\hline 1997 & 77 & 0 & 19 & 0 & 59 & 5 & 44 & 0 & 19 & 0 \\
\hline 1998 & 26 & 0 & 1 & 0 & 26 & 9 & 20 & 3 & 7 & 0 \\
\hline 1999 & 54 & 0 & 4 & 0 & 35 & 11 & 98 & 11 & 17 & 0 \\
\hline 2000 & 128 & 10 & 9 & 0 & 52 & 16 & 34 & 1 & 8 & 2 \\
\hline 2001 & 133 & 2 & 5 & 0 & 30 & 6 & 17 & 2 & 7 & 0 \\
\hline 2002 & 86 & 3 & 3 & 0 & 3 & 0 & 5 & 0 & 7 & 0 \\
\hline 2003 & 66 & 10 & 1 & 0 & 8 & 1 & 14 & 5 & 7 & 0 \\
\hline 2004 & 36 & 8 & 1 & 0 & 32 & 1 & 26 & 1 & 0 & 0 \\
\hline 2005 & 64 & 0 & 6 & 0 & 133 & 0 & 40 & 1 & 7 & 0 \\
\hline 2006 & 54 & 2 & 8 & 2 & 208 & 7 & 41 & 2 & 4 & 1 \\
\hline 2007 & 49 & 2 & 153 & 3 & 126 & 6 & 29 & 0 & 6 & 1 \\
\hline 2008 & 169 & 1 & 169 & 3 & 87 & 13 & 31 & 1 & 20 & 2 \\
\hline 2009 & 147 & 5 & 120 & 2 & 25 & 12 & 12 & 1 & 21 & 2 \\
\hline 2010 & 240 & 11 & 126 & 4 & 3 & 0 & 20 & 0 & 105 & 7 \\
\hline 2011 & 182 & 6 & 177 & 8 & 0 & 0 & 49 & 2 & 111 & 7 \\
\hline 2012 & 143 & 8 & 308 & 17 & 4 & 0 & 185 & 3 & 276 & 36 \\
\hline 2013 & 135 & 9 & 325 & 17 & 14 & 0 & 41 & 1 & 405 & 20 \\
\hline
\end{tabular}




\begin{tabular}{|c|c|c|c|c|c|c|c|c|c|c|}
\hline 2014 & 47 & 1 & 848 & 24 & 16 & 0 & 93 & 1 & 726 & 37 \\
\hline 2015 & 21 & 0 & 393 & 25 & 11 & 0 & 417 & 5 & 627 & 37 \\
\hline 2016 & 51 & 4 & 562 & 40 & 1 & 0 & 518 & 24 & 472 & 53 \\
\hline 2017 & 29 & 4 & 571 & 43 & 41 & 0 & 172 & 9 & 211 & 15 \\
\hline 2018 & 23 & 4 & 527 & 30 & 7 & 0 & 94 & 0 & 325 & 5 \\
\hline Totals & $\mathbf{2 1 3 5}$ & $\mathbf{9 0}$ & $\mathbf{4 5 0 2}$ & $\mathbf{2 1 8}$ & $\mathbf{2 9 1 8}$ & $\mathbf{1 1 4}$ & $\mathbf{3 7 6 0}$ & $\mathbf{7 6}$ & $\mathbf{3 4 5 8}$ & $\mathbf{2 2 5}$ \\
\hline
\end{tabular}

Comparing the national statistics reveals first that suicide attacks are never a preferred strategy, and rarely account for more than ten percent, typically much less, of the total terrorist attacks experienced by a country. More immediately relevant is the observation that suicide attacks do not begin to appear across nations at the same time, suggesting that their appearance is not a function of technological feasibility. For example, Lebanon was experiencing suicide attacks in the early 1980s, but they were not seen in Pakistan, despite a similar history of general terrorism, until the mid-1990s.

This irregularity is not accidental. Taking the wider view, Dechesne and Bandt-Law find enough consistency to argue that suicide terrorism arose in roughly four clusters across different periods and locations. ${ }^{87}$ If the resort to suicide attacks is therefore not dependent upon technology, what changes prompted the uneven resort to this new form of armed resistance?

In answering this question, we note that although the colonial era had largely passed by the 1980 s, the structural relationships it birthed have arguably been preserved with new economies that track the market domination of the Western powers. In other words, "the neo-colonialism of multi-national corporations is only the latest, most sophisticated form of indirect rule" that had typified the British empire. ${ }^{88}$ While many scholars study these developments from political or economic perspectives, Erich Fromm has argued that they also have a psychological impact:

Fromm argued that the more modernity advances, the smaller you feel. This is due to having lost touch with all the original "medieval ties" - clan, tribe, sect, guild, extended family, neighbourhood, etc. - that formed the premodern basis of personal identity. Modernity then has given birth to the individual while leaving him (or her) defenceless, alone and alienated against his opposite, society .... Thus the "individual overcomes the feeling of insignificance in comparison with the overwhelming

87. Dechesne \& Brandt-Law, supra note 25 , at 146.

88. Michael H. Fisher, Indirect Rule in the British Empire: The Foundations of the Residency System in India (1764-1858), 18 MOD. ASIAN STUD. 393, 395 (1984). 
power of the world outside of himself either by renouncing his individual integrity, or by destroying others so that the world ceases to be threatening."

In order to apply this insight, we need additional details on how this disruptive modernity was introduced into the impacted societies. The vector considered here is the spread of consumer capitalism. Developing societies, which often did not share the individualist consumer mentality upon which capitalist enterprises depend, nonetheless "were forced by financial pressures and international institutions to conform to the dominant American model of capitalism." 90 This policy, even when generating material benefits, on the whole resulted in a deterioration of local conditions.

Prior studies have shown that neither corporate globalization, ${ }^{91}$ nor economic development, ${ }^{92}$ is sufficient by itself to give rise to terrorist incidents within a country's borders. To achieve those economic goals in the developing markets, though, the worldviews of the subject population must be manipulated. ${ }^{93}$ This usurpation of the indigenous worldview, to be replaced with one radically different, one favoring transplanted market values, threatens an existential crisis. This process could explain the uneven introduction of suicide attacks.

Capitalism thrives not simply by making its goods available to new customers, but by aggressive advertising to create the perceived need for those goods. While early advertisements focused on the product's straightforward description and attributes, ${ }^{94}$ by the 1920 s marketing had shifted focus to new needs and insecurities that the offered products promised to fill. ${ }^{95}$ Advertising "helps to keep the masses dissatisfied with their mode of life, discontented with the ugly things around them. Satisfied customers are not as profitable as discontented ones." ${ }^{.96}$ As the classic

89. Aysha, supra note 32, at 85-86.

90. JAMES FulCHER, CAPITALISM: A VERY SHORT INTRODUCTION 98-99 (2nd ed. 2015).

91. Quan Li \& Drew Schaub, Economic Globalization and Transnational Terrorism: A Pooled Timed-Series Analysis, 48 J. CONFLICt ReSOL. 230, 254 (2004).

92. Martin Gassebner \& Simon Luechinger, Lock, Stock, and Barrel: A Comprehensive Assessment of the Determinants of Terror, 149 PUB. CHOICE 235, 254 (2011).

93. See generally Jonathan LeVy, Freaks of Fortune: The EMERging World of CAPITALISM AND RISK IN AMERICA (2012) (describing a study of changes that the rise of the capitalist economy provoked in the self-understanding of the individual, especially in the context of responsibility for ultimate economic success).

94. Monica Brasted, The Values of the Consumer Culture: Reflected in the Advertisements of "The Saturday Evening Post": 1900-1929 70 (2002) (Ph.D. dissertation, Pennsylvania State University) (on file with the Pennsylvania State University system).

95. WinStON FlETCHER, AdVERTISING: A VERY SHORT INTRODUCTION 99 (2010).

96. STUART EWEN, CAPTAINS OF CONSCIOUSNESS: ADVERTISING AND THE SOCIAL RoOTS OF CONSUMER CULTURE 39 (1976). 
sociological study Middletown recounts, advertising since the turn of the century concentrated "increasingly upon a type of copy aiming to make the reader emotionally uneasy, to bludgeon him with the fact that decent people don't live the way he does. ${ }^{.97}$ Famous examples of creating insecurities to sell merchandise include the histories of antiperspirants ${ }^{98}$ and mouthwash. ${ }^{99}$ Consequently,

[a] major outcome of globally mediated promises of a good life has been that people around the world perceive their immediate lifeworld as worthless and hopeless. As a consequence, "globalization is by many people primarily experienced in its absence, in the form of the non-arrival of change, unfulfilled promises and aspirations rather than in an actual increase of mobility or flux of goods." 100

Cast in the terms of the present argument, for capitalism to succeed it must not only undermine the self-esteem prong of TMT, but also substitute itself as a competing view of the standards by which consumers will adjudge themselves to be significant. ${ }^{101}$

Consumer values serve to assign meaning and significance to the individual's existence, and in that way emerge as a competing culturally fostered solution to the death paradox. In this context, Becker specifically analyzed money as the "new universal immortality ideology." 102 Gold and money has become, he says, the immortality symbol for the West. ${ }^{103}$ Tennessee Williams described the relationship this way:

The human animal is a beast that dies and if he's got money he buys and buys and buys and I think the reason he buys

97. Robert S. Lynd \& Helen Merrill Lynd, Middletown: A Study In CONTEMPORARY AMERICAN CULTURE 82 (1929).

98. Sarah Everts, How Advertisers Convinced Americans They Smelled Bad, SMITHSONIAN MAG. (Aug. 2, 2012), https://www.smithsonianmag.com/history/how-advertisers-convinced-americans-they-smelled-bad-12552404/.

99. Laura Clark, How Halitosis Became a Medical Condition With a "Cure", SMITHSONIAN MAG. (Jan. 29, 2015), https://www.smithsonianmag.com/smart-news/marketing-campaign-invented-halitosis-180954082/.

100. Joska Samuli Schielke, Egypt in the Future Tense: Hope Frustration, And AMBIVALENCE BEFORE AND AFTER 201135 (2015) (quoting Knut Graw).

101. Brasted, supra note 94, at 31 ("The consumer revolution is now seen to have changed the Western concepts of time, space, society, the individual, family and state. The meanings carried by goods resocialize "the people," change their concepts of themselves, their concepts of society and most of all their social aspirations by changing their concept of consumption and consumer goods.").

102. ERNEST BECKER, ESCAPE FROM EVIL 73-90 (1975).

103. Id. at 74; Tyler F. Stillman \& Lindsey A. Harvell, Marketing, Money, and Mortality, in DENYING DEATH: AN INTERDISCIPLINARY APPROACH TO TERROR MANAGEMENT THEORY 84, 84-85 (Lindsey A. Harvell \& Gwendelyn S. Nisbett eds., 2016). 
everything he can buy is that in the back of his mind he has the crazy hope that one of his purchases will be life everlasting. ${ }^{104}$

The rise of this new significance strategy inevitably sparks competition with prior worldviews. But whereas traditional religions tend to be anxiety-reducing institutions, capitalism thrives by creating anxiety, not alleviating it. That reversal makes it an exceptionally poor replacement for the prior death anxiety solutions.

Even in the United States, where one might expect the hedonic benefits of material consumption to be the most plainly visible, one finds the opposite. Excessive choices arising from material abundance cumulatively cause distress that results from "regret, concern about status, adaptation, social comparison, and perhaps most important, the desire to have the best of everything - to maximize." ${ }^{105}$ This "tyranny of small decisions," 106 which has been shown to "contribute to the recent epidemic of clinical depression affecting much of the Western world," 107 is embedded in a broader context wherein the necessity of material acquisition serves as the means to social acceptability, leading Americans to feel the perpetual humiliation of never having enough. ${ }^{108}$

As a result, about $20 \%$ of adults in the United States suffer from a mental illness, and for $4.6 \%$ of adults these issues are serious. ${ }^{109}$ In one comparative study, the $26.4 \%$ of Americans who have experienced any of the recorded Diagnostic and Statistical Manual of Mental Disorders [fourth edition (DSM-IV)] illnesses in the last twelve months ranked the highest out of fourteen countries. ${ }^{10}$ We have seen increased psychopathology among college students, ${ }^{111}$ with the suicide rate among younger Americans increasing dramatically from 1999 to $2017 .{ }^{112}$

104. TenNesseE Williams, CAT ON A Hot Tin RoOF 45-46 (1954).

105. BARry SCHWARTZ, THE PARAdOX OF CHOICE: WHY MORE IS LESS 221 (2004).

106. Id. at 21 .

107. Id. at 5 .

108. Id. at 191-92.

109. U.S. Dept. of Health and Human Services, Key Substance Use and Mental HEALTH INDICATORS IN THE UNITED STATES: RESUltS FROM THE 2018 NATIONAL SURVEY ON DRUG USE AND HEALTH 43-44 (2019).

110. Koen. Demyttenaere et al., Prevalence, Severity, and Unmet Need for Treatment of Mental Disorders in the World Health Organization World Mental Health Surveys, 291 JAMA 2581, 2584 (2004).

111. Jean M. Twenge et al., Birth Cohort Increases in Psychopathology Among Young Americans, 1938-2007: A Cross-Temporal Meta-Analysis of the MMPI, 30 CLINICAL PSYCH. REV. 145, 149, $152(2010)$.

112. U.S. DeP'T of Health And Hum. Servis., CS298851, Suicide Mortality in the United States, 1999-2017 (2018); Oren Miron et al., Suicide Rates Among Adolescents and Young Adults in the United States, 2000-2017, 321 J. AM. MED. Ass’N 2362, 2362 (2019). 
These outcomes are unsurprising when viewed against the change in United States' commercial morality from the 1920s, when the patent for the isolation of human insulin was transferred for the public good for a token $\$ 1.00$. In the present day, United States' drug company CEOs raise the costs of their medicines enormously in the belief that, "it is a moral requirement to make money when you can." ${ }^{113}$ Under the push of advertising, in sum, the last hundred years has seen our cultural emphasis shift from ideals of intrinsic virtues to those of extrinsic materialism.

All told, to the extent that "people have adopted the 'American dream' of stuffing their pockets, they seem to that extent to be emptier of self and soul." 114 It is important to note that this outcome is not because consumer capitalism has been abused or poorly implemented. The negative effects flow from the way that capitalism necessarily operates. Capitalism by definition creates desires that can never be satisfied:

This is the genius of the capitalist process: by actually providing goods and gratifications on the condition of constant growth, capitalism constantly raises expectations, undermines lives and livelihoods that once were safe and certain, and creates pressures and promises that once would have been unimaginable. These pressures are troublesome even under conditions of relative wealth. ${ }^{115}$

The last point is striking. To argue, as some do, that the system "works" because poor people are better off than poor people were a hundred years ago ${ }^{116}$ misses the point, because life satisfaction is not a simple function of what a person has, but also what he has relative to others. ${ }^{117}$ As Marx had earlier noted, as societies become wealthier, people redefine what subsistence means. ${ }^{118}$ Because the standards necessarily recede beyond reach, the new religion of wealth, in the end, does not and inherently cannot perform adequately as a death paradox-mitigating worldview.

113. Jessie Hellmann, Drug Company CEO Calls 400 Percent Price Hike 'Moral Requirement,' THE HILL (Sept. 11, 2018), https://thehill.com/policy/healthcare/406103-ceo-of-drug-company-calls-400-percent-price-increase-moral-requirement.

114. Tim KASSER, THE High PRICE OF MATERIALISM xi (2002).

115. SCHIELKE, supra note 100, at 227.

116. Marian L. Tupy, Global Poverty's Defeat Is Capitalism's Triumph, CATO InST. (Oct. 10, 2015), http://www.cato.org/publications/commentary/global-povertys-defeat-capitalisms-triumph.

117. Robb B. Rutledge et al., The Social Contingency of Momentary Subjective Well-Being, NATURE COMMC'NS, June 2016; ATRAn, supra note 38, at 8. See W.G. RunCiman, Relative DEPRIVATION AND SOCIAL JUSTICE (Univ. of Cal. Press ed. 1966) (explaining an early work on the problem of relative deprivation).

118. Richard Nordahl, A Marxian Approach to Human Rights, in CROSS-CUlTURAL PERSPECTIVES: A QUEST FOR CONSENSUS 162, 171 (Abdullahi Ahmed An-Na'im ed., 1992). 
Despite these significant negative consequences, and because capitalism must expand into new markets to survive, this failed worldview is aggressively imposed across the globe because of the one dimension on which capitalism does perform well - raw monetary benefits. Market capitalism is backed by massive military and economic coercive power to the detriment of the traditional institutions that offered more effective solutions to the death paradox. Thus, market capitalism has been introduced into cultural environments that did not contain the elemental precursors that would have made it less of an alien intrusion. The result has been a transition from a society of communally-based independent producers into one of individualistic passive consumers, a change that has proved traumatic even for Americans. ${ }^{119}$

It is in this sense that one may view the incursion of capitalist values as a forced religious conversion ${ }^{120}$ that some may not happily endure, leading in some instances to dramatic blowback. This is the background against which the differential appearance of suicide terrorism becomes comprehensible. The exportation of American values of "relentless consumerism, atomized societies, the interpretation of freedom as no rules and no responsibility, and glorification of vulgarity and violence in film and music" which "steal[] the identity of the oppressed," offers nothing but "a new colonial system"121 that creates a "source of potential humiliation and worldview threat that could increase the appeal of radical Islamist movements." $" 122$

According to Atran once said the following, "Violent extremism represents not the resurgence of traditional cultures but their collapse as young people unmoored from millennial traditions flail about in search of a social identity that gives personal significance and glory. This is the dark side of globalization." 123

Here, he restates an observation first recorded by Hoffer almost seventy years earlier: "The discontent generated in backward [sic] countries by their contact with Western civilization is not primarily resentment against exploitation by domineering foreigners. It is rather the result of a crumbling or weakening of tribal solidarity and communal life." 124 The new element to be considered is how cultural factors may have shaped

119. EWEN, supra note 96 , at 58 .

120. Roni Zirinski, Ad Hoc ARABism: Advertising, Culture, ANd TeChNOlogy in SAUDI ARABIA 133 (2005).

121. Jessica Stern, Terror In the NAme OF God: Why Religious Militants Kill 295, 283, 40 (2003).

122. Pyszczynski et al., supra note 77 , at 22 .

123. Atran, supra note 52, at S199.

124. HOFFER, supra note 34 , at 38. 
the acceptable form of suicide in some Middle Eastern societies. ${ }^{125}$ In the face of foreign values that contradict the local death-denying mores, "If one is chronically unsuccessful at convincing oneself of the inferior nature of the competing [cultural worldview], a more grim, final solution, as so many terrorist fascists have concluded, is simply to obliterate the offending presence." ${ }^{26}$ TMT thus predicts what SQT cannot:

[C]onfidence in a particular worldview can be restored by annihilating those who do not share that view, thus proving conclusively that the victor must have been right after all. From this perspective, then, prejudice (and the violent conflicts that often result from it) can be understood, at least in part, as an inevitable consequence of competition between death-denying cosmological visions. ${ }^{127}$

The hypothesis here is that pressure on existing worldviews in places into which the West has prematurely introduced a capitalistic mindset began to reach a cultural tipping point in the years leading up to the 1980s. The empirically observed differential resort to suicide terrorism is therefore a function of the timing of the full brunt of capitalist insertion and the degree to which Western-style consumerism has undermined the local techniques for death denial. For resistors, the choice becomes either to capitulate to the new worldview that is demonstrably inferior in terms of resolving the death paradox, thereby leading to pathological anxieties, or to aggressively reassert and defend the old lifeways that let one feel that life is meaningful. In this confluence of competing cultural forces, suicide attacks whereby actors seek to preserve their immortality, rather than their lives, become a comprehensible strategy.

\section{EGYPTIAN CASE STUDY}

A look at the rise of suicide terrorism in Egypt provides initial realworld support for the proposed relationship between suicide attacks and the disruptive influence of Western market values upon traditional societies.

125. In this light, suicide terrorism may also be viewed as a form of culture-bound syndrome, like latah, and koro, but especially Malay amok, a form of "sudden mass assault." See THE CUlTuRE-BOUnd SYNDROMES: FOLK ILLNESSES OF PSYCHIATRIC AND ANTHROPOLOGICAL INTEREST (Ronald C. Simons \& Charles C. Hughes eds., 1985).

126. Claude H. Miller \& Mark J. Landau, Communication and Terrorism: A Terror Management Theory Perspective, 22 COMMC'N RSCH. REPS. 79, 82 (2005).

127. Jeff Greenberg et al., Terror Management Theory of Self-Esteem and Cultural Worldviews: Empirical Assessments and Conceptual Refinements, 29 ADVANCES IN EXPERIMENTAL SOC. PSYCH. 61, 70 (1997), https://doi.org/10.1016/S0065-2601(08)60016-7. 
Table 1 shows that while Egypt has had an extensive history of terrorist attacks, the first use of suicide terrorism did not occur until 1993. In contrast, Lebanon experienced suicide attacks beginning in at least 1981. As argued, that twelve-year lag suggests that technological innovation is not the spark that drives the method's appearance. An alternative explanation emerges from the observation that in both cases, the terrorist attacks can be correlated with total imported goods into the country from the United States.

Table 2 presents the correlation of terrorist attacks with imported commodities in both countries. All tables and graphs in this Part are drawn from the START data recorded in Table 1, compared with country trade statistics taken from the International Trade Centre's tables covering 2001-2019. ${ }^{128}$ The results show uneven support for this theory. In Egypt, the chosen test case, suicide attacks have weaker correlations with imports of United States' commodities than does non-suicide terrorism, contrary to expectations. The Lebanon results are similarly unimpressive: although both relationships are weak, the suicides are slightly behind general terrorist attacks.

\begin{tabular}{|l|c|c|c|c|c|c|}
\hline \multicolumn{7}{|c|}{ Table 2: Total US Imports X Terrorist Attacks } \\
\hline & $\mathbf{2 0 0 1}$ & $\mathbf{2 0 0 2}$ & $\mathbf{2 0 0 3}$ & $\mathbf{2 0 0 4}$ & $\mathbf{2 0 0 5}$ & $\mathbf{2 0 0 6}$ \\
\hline $\begin{array}{l}\text { EGYPT } \\
\text { Total US Imports }\end{array}$ & $1,832,166$ & $1,684,285$ & $1,272,951$ & $1,351,227$ & $1,769,758$ & $1,603,710$ \\
\hline Suicide Att. & 0 & 0 & 0 & 3 & 2 & 0 \\
\hline Non-Suicide & 0 & 0 & 0 & 0 & 0 & 5 \\
\hline $\begin{array}{l}\text { LEBANON } \\
\text { Total US Imports }\end{array}$ & 515,957 & 466,043 & 432,306 & 554,268 & 548,532 & $1,038,611$ \\
\hline Suicide Att. & 0 & 0 & 0 & 0 & 0 & 1 \\
\hline Non-Suicide & 5 & 8 & 5 & 1 & 17 & 7 \\
\hline & $\mathbf{2 0 0 7}$ & $\mathbf{2 0 0 8}$ & $\mathbf{2 0 0 9}$ & $\mathbf{2 0 1 0}$ & $\mathbf{2 0 1 1}$ & $\mathbf{2 0 1 2}$ \\
\hline $\begin{array}{l}\text { EGYPT } \\
\text { Total US Imports }\end{array}$ & $2,571,843$ & $5,673,135$ & $4,744,216$ & $4,961,898$ & $6,470,100$ & $5,276,494$ \\
\hline Suicide Att. & 0 & 0 & 0 & 0 & 2 & 0 \\
\hline Non-Suicide & 0 & 1 & 2 & 2 & 16 & 49 \\
\hline $\begin{array}{l}\text { LEBANON } \\
\text { Total US Imports }\end{array}$ & $1,140,911$ & $1,848,558$ & $1,770,103$ & $1,919,314$ & $1,994,558$ & $2,375,536$ \\
\hline Suicide Att. & 1 & 1 & 0 & 0 & 0 & 0 \\
\hline Non-Suicide & 17 & 57 & 14 & 5 & 10 & 15 \\
\hline & $\mathbf{2 0 1 3}$ & $\mathbf{2 0 1 4}$ & $\mathbf{2 0 1 5}$ & $\mathbf{2 0 1 6}$ & $\mathbf{2 0 1 7}$ & r \\
\hline $\begin{array}{l}\text { EGYPT } \\
\text { Total US Imports }\end{array}$ & $5,214,723$ & $5,198,838$ & $4,378,825$ & $3,095,178$ & $3,896,808$ & \\
\hline Suicide Att. & 9 & 5 & 16 & 9 & 16 & .20 \\
\hline Non-Suicide & 312 & 349 & 631 & 367 & 208 & .29 \\
\hline $\begin{array}{l}\text { LEBANON } \\
\text { Total US Imports }\end{array}$ & $1,500,404$ & $1,226,783$ & $1,024,379$ & $1,184,073$ & $1,048,133$ & \\
\hline & & & & & & \\
\hline
\end{tabular}

128. International Trade in Goods - Imports 2001-2019, INT'L TRADE CTR., http://www.intracen.org/itc/market-info-tools/statistics-import-product-country/ (last visited Nov. 14, 2020). 


\begin{tabular}{|l|c|c|c|c|c|c|}
\hline Suicide Att. & 6 & 13 & 4 & 2 & 2 & .04 \\
\hline Non-Suicide & 115 & 191 & 40 & 39 & 21 & .15 \\
\hline
\end{tabular}

The proposal, however, does not describe a one-to-one relationship between marketing and suicidal terrorism such that imports influence attitudes and spur attacks all in the same year. While cultural shocks that lead to such immediate effects are possible, the more likely progression will be a sequence of influences from commodity introduction and advertising to perceived weakening of local norms, culminating in an existential crisis that triggers the possibility of suicidal defense. In other words, the model locates the cause for suicide attacks not in contemporaneous foreign imports, but as flowing from the repercussion of earlier imports.

To test this possibility, the import data was projected forward for each of ten years to see what pattern emerged. Table 3 summarizes the way time-shifting the trade data impacts correlations with attacks. This relationship for Egypt is visually represented in Graph 1.

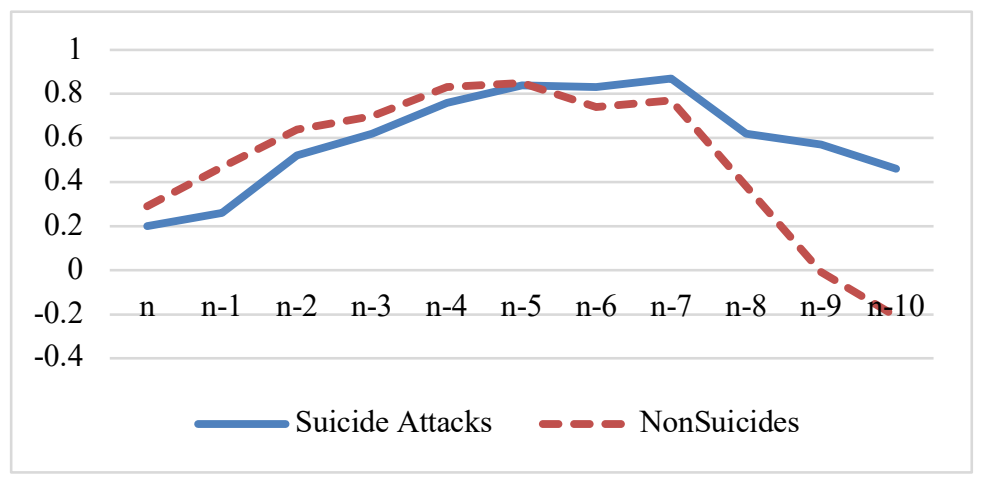

Graph 1: Time-Shifted Imports x Attacks Correlations (Egypt)

\begin{tabular}{|l|c|c|c|c|c|c|}
\hline \multicolumn{6}{|c|}{ Table 3: Time-Shifted Imports x Terrorist Attacks Correlations } \\
\hline EGYPT & N & N-1 & N-2 & N-3 & N-4 & N-5 \\
\hline Suicide & 0.20 & 0.26 & 0.52 & 0.62 & 0.76 & 0.84 \\
\hline Non-Suicide & 0.29 & 0.47 & 0.64 & 0.07 & 0.83 & 0.85 \\
\hline LEBANON & $\mathbf{N}$ & $\mathbf{N}-1$ & $\mathbf{N}-2$ & $\mathbf{N}-3$ & $\mathbf{N}-4$ & N-5 \\
\hline Suicide & 0.08 & 0.29 & 0.59 & 0.54 & 0.51 & 0.52 \\
\hline Non-Suicide & 0.15 & 0.37 & 0.62 & 0.48 & 0.44 & 0.41 \\
\hline EGYPT & $\mathbf{N}$ & $\mathbf{N}-6$ & $\mathbf{N}-7$ & $\mathbf{N - 8}$ & $\mathbf{N}-9$ & N-10 \\
\hline Suicide & 0.20 & 0.83 & 0.87 & 0.62 & 0.57 & 0.46 \\
\hline Non-Suicide & 0.29 & 0.74 & 0.77 & 0.38 & -0.01 & -0.21 \\
\hline LEBANON & $\mathbf{N}$ & $\mathbf{N}-6$ & $\mathbf{N}-7$ & $\mathbf{N}-8$ & $\mathbf{N}-9$ & $\mathbf{N}-10$ \\
\hline Suicide & 0.08 & 0.57 & 0.34 & 0.19 & -0.1 & -0.22 \\
\hline
\end{tabular}




\begin{tabular}{|l|l|l|l|l|l|l|}
\hline Non-Suicide & 0.15 & 0.42 & 0.16 & 0.08 & -0.22 & -0.3 \\
\hline
\end{tabular}

As applied to Egypt, the model performs well. The correlation favors both general and suicide terrorism for the first five years after a market disruption. Thereafter, the relationship with general terrorism begins to fall to the extent that by ten years later, the correlation is negative. The rate of suicide attacks, however, continues to rise. Although the rate has decreased in later years, it remains well above both the correlation for general terrorism and initial values towards the end of the examined term. This is the pattern one would anticipate if the resort to suicide attacks comes after an extended process of weakening and dissatisfaction with the effectiveness of the traditional immortality projects. ${ }^{129}$

For comparison, Graph 2 shows the same relationships for Lebanon. Again, general terrorist attacks display a slightly better relationship with American imports than do suicide attacks; however, two years later the types of attacks cross over and suicide attacks remain more correlated with imports for the next four years. After the sixth year, both forms of attacks decrease. By the end of the sequence, although both correlations are negative, suicide attacks remain above general attacks. ${ }^{130}$

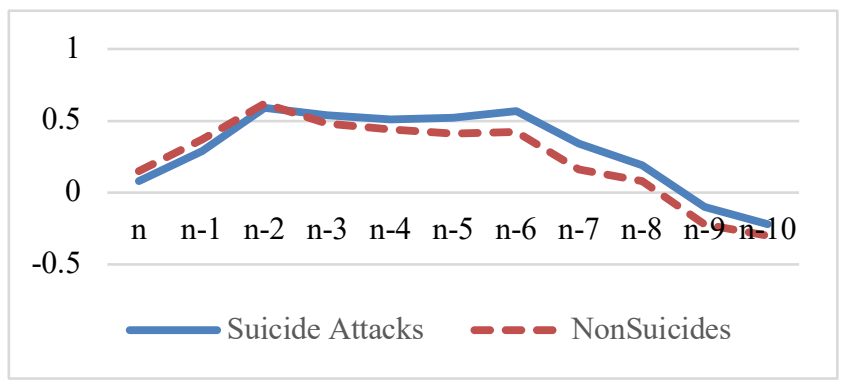

Graph 2: Time-Shifted Imports x Attacks Correlations (Lebanon)

The broad conclusion from this comparison is that to the extent that the posited relationship exerts an influence on the incidence of suicide terrorism, it varies for each country. According to the graphs, the introduction of suicide attacks into Egyptian conflicts is linked not to market forces in 1993, but instead the market conflicts of 1986. In contrast, in

129. Although the current initial investigation treats trade data as a single isolated point, further refinements would account for trade as an ongoing additive social input over several years.

130. On a broad methodological note, future investigations, rather than comparing total U.S. imports, should consider that the predicted relationship holds mainly in categories containing luxury goods that reflect status and self-esteem rather than life necessities. For example, description of the problem suggests that items of personal significance such as clothing and toiletries risk a more disruptive cultural influence than imports of basic foodstuffs like grains. 
Lebanon, market changes in the mid-1970s would lead to the comparatively early use of suicide attacks. ${ }^{131}$

The overall feasibility of the model receives additional support from an independent perspective: the subjective perceptions of Egyptians as reported in ethnographies. From these descriptions we learn that new consumer patterns have significantly impacted the lives of ordinary Egyptians, and largely for the worse. Samuli Schielke, working among rural, lower middle class men in villages in northern Egypt, recognized that over the past decades "sustained economical growth [has] filled the cities' streets ... . with private cars and new red-brick buildings of up to six floors [having] transformed the appearance of villages."132 Unfortunately, this material bounty has exacted a steep price. Objectively, Egyptians appear to be better off; yet amidst this prosperity "almost everyone bitterly complained about increasing economic pressure, corruption and nepotism, and deepening social divisions."133

The difficulties associated with marriage illustrate this tension between the economic advantages from the new capitalism and the increased psychological pressures. "One of the greatest paradoxes of life in contemporary Egypt is that in a society where marriage is considered a self-evident, destiny-like necessity, it has become increasingly difficult to get married. The primary reason for that difficulty is the rising cost of marriage." ${ }^{134}$ Indeed, anthropologist Farha Ghannam in her writings about her work with a low-income neighborhood in Cairo states that, "[G]etting married has become more and more challenging," leading to a "marriage crisis" in Egypt. ${ }^{135}$

At first glance, this may not strike the Western reader as a unique problem. The costs of weddings have risen significantly in most societies,

131. Accessible longitudinal economic data from Lebanon from available sources such as the World Bank and the official Lebanon Central Administration of Statistics do not report data earlier than the mid-1980s, so it has not been possible to pursue this suggestion further.

132. SCHIELKE, supra note 100, at 154-55.

133. Id. at 155 .

134. Id. at 112 .

135. FARNA GHANNAM, LiVE AND DiE LiKe A MAN: GENDER DyNAMICS IN URBAN EGYPT 72 (2013). Id. at 80 ("This change has been shaped by global flows of information, images, and products, and the increasing emphasis on consumption and its role in daily life in general and the management of the body in particular."). See also SCHIELKE, supra note 100, at 114 ("[B]ecause people consider marriage a singularly important form of social becoming, and because of the availability of more and more consumer goods, better housing conditions, and the income and/or credit to finance them, the cost of marriage is constantly magnified, to the degree that people can barely afford it and so end up waiting much longer than previously was common to get married."). 
with the average cost in the United States approaching $\$ 34,000 .{ }^{136}$ However, the real difficulty arises from the compulsory nature of these expenses. The problem, as Schielke's informants describe, is that "while most Egyptians can now buy many more things than they could twenty or fifty years ago, buying those things is not something one can choose to do in most cases, they are things one must buy, even if they may seem a dispensable luxury to an outsider ... [C]onsumption is not a choice. It is a necessity." "137 The marriage suitor is expected to have accumulated a significant list of goods, while the standard of what is deemed acceptable by the woman's family is continuously rising. Consequently,

the existential comfort of having a little more than one needs has transformed into something more peculiar: an anxious combination of pressure and aspiration to realize a constantly better life by accumulating more wealth .... [M]any among those people do not experience growth as a comforting margin of surplus. Instead, they experience it as pressing scarcity .... ${ }^{138}$

This social pressure to consume has been accompanied by new forms of advertising to hawk those wares and to create the perceived needs. For example, a Turkish report states that,

[o]ne prominent material consumer object that has played a major role in the transformation of modern Turkey identity is the diamond solitaire engagement ring. Formerly a status symbol of the wealthy, the solitaire now, thanks to a massive media campaign by DeBeers' Diamond Trading Company (DTC) and the 2006 song "Pirlanta" ("Diamond") by Turkish pop singer Nil Karaibrahimgil, has been embraced by the new emerging middle class, and as a result, can be found in every mall jewelry shop. ${ }^{139}$

One survey found that "almost $82 \%$ [of survey takers] ... acknowledge that print ads are currently much more focused on sex" which offended most Egyptian respondents, but were deemed inoffensive

136. Anna Hecht, Here's How Much the Average Wedding Cost in 2019, CNBC (Feb. 14, 2020, 11:01 AM), https://www.cnbc.com/2020/02/13/how-much-the-average-wedding-cost-in-2019. html.

137. SCHIELKE, supra note 100, at 115 .

138. Id. at 119.

139. Tanfer Emin Tunç, Between East and West: Consumer Culture and Identity Negotiation in Contemporary Turkey, in MuSLIM SOCIETIES IN THE AGE OF MASS CONSUMPTION: POLITICS, Culture AND IdENTITy BetWeEn the LocAl AND the Global 73, 78-79 (Johanna Pink ed., 2009). 
by most non-Egyptians. ${ }^{140}$ In other words, while the rise of consumer expectations is inherently anxiety-provoking, the baseline pressures are exacerbated by the accompanying ancillary services that support that market economy. Commercials "overwhelmingly feature blond Egyptians (and often blond foreigners with Egyptian voice-over), racy clothes, and a generally Western-oriented attitude," 141 which stir up further discomfort in local societies.

The negative effects of consumer capitalism are not completely inevitable. The narrative should not be framed as a necessary clash between Western values and Middle Eastern traditions. Societies and individuals are equipped to make the transition as best one can. For example, Johanna Pink collected essays describing largely unproblematic incorporation of consumer values in a range of Muslim societies. ${ }^{142}$ To "interpret Egyptian popular culture either as a straightforward imitation of the West or, conversely, as cryptic resistance to hegemonic power, would as often as not lead one to misunderstand the character of the art." 143 Instead of a conflict of cultures, Egyptians "aspire to make global modernity their own, without becoming homogenized or fully connected in the sense evoked by globalization." "144 Although the effort at syncretism can itself be problematic, ${ }^{145}$ the immediate lesson here is that the process is challenging. Even if the process is largely successful across a population, a significant minority may feel so alienated as to seek a different path to resolution. The fuller development of the present model would operationalize the size of the excluded population and the force and abruptness of the market insertions to capture the variability of incidents of suicide terrorism by civilians.

The impact of these influences can strike deeply into the psyche of that population, complicating already tenuous developmental processes. For example, the "growing emphasis on consumption" has impacted the structure of men's self-identity. ${ }^{146}$ However, the means to achieve this recognized adult status can often compel individuals "to make

140. Christine SAmy, Stereotyping AND SEXISM In AdVERTISING: AN EMPHASIS ON THE PORTRAYAL OF WOMEN IN EGYPT 32, 50 (2016).

141. WAlter ARmburst, Mass Culture AND Modernism In EGypt 131 (1996).

142. See generally Muslim Societies in the AgE of Mass Consumption: Politics, Culture AND IDENTITY BeTweEn the LoCAL AND THE GlobAL (Johanna Pink ed., 2009).

143. ARMBURST, supra note 141 , at 3.

144. SCHIELKE, supra note 100 , at 153.

145. See e.g., id. at 20 (focusing on the nexus of capitalist consumption and revivalist ethics, [Carla] Jones argues that "while pious fashion promises a solution to the troublesome and contradictory demands of virtue and fashion, it is a tragic attempt, because pious consumption actually reproduces precisely those anxieties about vanity and virtue that it promises to alleviate").

146. GHANNAM, supra note 135 , at 71 . 
compromises that potentially undermined his view of himself as a man in order to satisfy the requests of others that were essential to socially producing him as a man." ${ }^{147}$ To acquire the external markers of manhoodwhich are largely procured in the marketplace - it can be necessary to breach the values that constitute the internal achievements of manhood. In sum, there seem to be few ways for the ordinary person to succeed at the common goals of life in this new, consumer-oriented society without paying a high psychological toll.

Many informants report being overwhelmed by these forces, leading to a state of anxiety that Schielke's sources describe as feeling "bored," a term drawing upon the world-weariness associated with the related condition of ennui. Boredom, perhaps paradoxically, "came to the village hand in hand with education, mass media, and mobility," 148 or the kinds of developments that might be expected to lead to new, exciting opportunities. Instead, boredom "is more an existential state of lacking of future and hope, which is intimately coupled with frustration and often close to despair." 149 In keeping with the existential philosophers in the West, Egyptians believe that the "solution to boredom is doing something meaningful." 150

As previously described, a wide range of cultural solutions responds to the need to find meaning in a life experienced as pointless and unfulfilling. Indeed, anything at all can serve the purpose, so long as it is assigned the role of "ultimate concern" in the individual's psychology. ${ }^{151}$ But without question, the institution specifically tailored to this task is religion: "[r]eligious armor allows one to cope with life's disappointments in an unknown, modern, pluralistic world, when everyday control is removed, and thus supra-human power is required." 152 Both of these generalizations are found in the reasons given to account for one of Schielke's informant's turn toward Salafi fundamentalism as following upon an urgent personal crisis experienced as a moral vacuum. In

147. Id. at 94 .

148. SCHIELKE, supra note 100 , at 34 .

149. Id. at 32 .

150. Id. at 46 .

151. James Michael Donovan, Defining Religion: Death and Anxiety in an Afro-Brazilian Cult 105-106 (1994) (Ph.D. dissertation, Tulane University); see also James Michael Donovan, Defining Religion, in SElECTED REAdINGS IN THE ANTHROPOlOGY OF RELIGION: THEORETICAL AND METHOdOlOGiCAL ESSAYS 61, 87 (Stephen D. Glazier \& Charles A. Flowerday, eds., 2003).

152. Ragnar K. Willer, The Re-Spiritualization of Consumption or the Commercialization of Religion: Creativity, Responsibility, and Hope: The Case of Sunsilk Clean and Fresh in Indonesia, in Contemporary Turkey, in MUSLIM SOCIETIES IN THE AGE OF MASS CONSUMPTION: POLITICS, Culture and Identity Between the Local and the Global 281, 290 (Johanna Pink ed., 2009). 
Mustafa's words, it was a matter of urgently wanting to be able to "know right from wrong." 153 Interestingly, Mustafa's later military service served the same purpose, "[t]he military service kept him busy, and in a peculiar fashion it offered him something of the same thing he had been searching for in Salafism." Mustafa stated, "I feel at peace because everything has a clear structure, you don't have to think for yourself."

Having experienced the anxiety-provoking effects of living in a consumer-oriented society, people seeking a better solution, such as Mustafa, often seek out religion. ${ }^{155}$ For many, this newfound immersion in religious orthodoxy has been effective. Among Schielke's informants, those involved in religion claimed to have found a way to avoid the pitfalls of "boredom": "[w]e as Muslims do not feel so much boredom because when you pray regularly, it gives you hope again every time." 156

Consequently, "[a]mong the Muslim majority of the population, an Islamic revival has made a scripturally-oriented and conservative sense of religiosity the most powerful source of moral certainty and existential hope." ${ }^{157}$ However, the decision to rely on religious belief to serve this psychological role creates its own secondary anxieties that lead to "the cultivation of an anxious vigilance toward anything that could relativize the certainty of religion as an absolute truth about all interpretation, negotiation, and reconciliation." ${ }^{158}$ Religious commitment in this environment takes the form of "a double move of emphatic attachment to a shared ground of truth and certainty, and a heightened anxiety and sensitivity toward those who do not share that firm ground."159

While Westerners might rely upon compartmentalization to avoid the full thrust of the cognitive dissonance between conflicting values, ${ }^{160}$ many Egyptians find that approach unsustainable:

It might seem as if different worlds stood here side by side: the world of Islam as a regime of divine protection, order, and justice; the world of global capitalism with its investment in financial schemes; the world of commercial media with its reliance on consumerism, advertisement, and desire; the world of

153. SCHIELKE, supra note 100 , at 131.

154. Id. at 131-32.

155. WALTER ARMBURST, MARTYRS AND TRICKSTERS: AN ETHNOGRAPHY OF THE EGYPTIAN REVOLUTION 151 (2019) (quoting Hasanayn 'Abd al-Rahman).

156. SCHIELKE, supra note 100, at 44 (quoting Hilmi, an informant).

157. Id. at 3 .

158. Id. at 79-80.

159. Id. at 15 .

160. David Berliner, Anthropology as the Study of Contradictions, 6 HAU: J. ETHNOGRAPHIC THEORY 1, 2-3 (2016). 
romantic love with its celebration of passion. But these are not different worlds. They are constituents, parts, of people's lifeworlds - lifeworlds that can never be explained by any single principle but that must be understood in their complexity and openness, in their many hopes and frustrations. ${ }^{161}$

The result for some Egyptians is that, in order to avoid a breakthrough of the contrary examples of personal meaning, the threat of existential anxiety can lead to defensive reactions against the new values. Closing the argument, we finally learn that "[p]eople often also see boredom and depression as related phenomena, and in one occasion people I talked with also associated boredom with the issue of suicide."162

Suicide for Egyptians, according to Ghannam, is not necessarily the manifestation of a sickly attitude toward life, as it is for Westerners, but can instead be a path to the valued "good ending":

One may be tempted to understand the Egyptian notion of good ending as a negation of life, a sign of fatalism and irrationality, a call for people to value only the afterlife and ignore the current one. As argued by Charles Hirschkind, for "many in the West today, Muslim discourses on death are taken as evidence of a diseased culture, one frequently epitomized in the figure of the suicide bomber." Yet this simplistic and hasty conclusion does not capture how the notion of good death establishes a strong relationship between this life and the afterlife, between one's religious devotion and engagement with the community, and between one's deeds and intentions .... [R] [Rther than a sign of fatalism, the notion of good death is a sign of realism. Instead of denying death, distancing it from the self, and turning it into a taboo that should be hidden, the meaning of the good ending highlights the fact that no one can escape death and offers ways to manage this biological, social, and religious fact .... [T]he notion of good death in fact encourages a deep ethical and practical engagement in the life of one's family and community."163

Having begun with the increased consumerism within Egyptian society, the ethnographic narrative traces how the ramifications of those changes can lead many to experience "boredom" as a result of new insecurities arising from economic pressures, which in turn influences a small portion of these individuals to consider suicide as an appropriate manner to resolve these contradictions with a "good ending." This approach may

161. SCHIELKE, supra note 100 , at 12.

162. Id. at 32 .

163. GHANNAM, supra note 135 , at 159. 
combine with a renewed religious commitment in order to remedy the existential vacuum created by reliance on the inferior and contradictory consumer-driven values. The two pressures can converge, mutually reinforcing one another into a lack of tolerance for contradictory views. This concatenation of influences may be comparatively rare, but when they occur the result can be literally explosive.

\section{SUMMARY AND CONCLUSION}

Terrorism, while a problem, is not a mystery. The motivations of actors to resort to nonconventional military methods to press their interests are not conceptually dissimilar to the strategies of soldiers on more traditional battlefields. However differently the law may treat the actions, the individual psychologies that motivate the violence employ the same elements, albeit to different effects.

The same cannot be said about suicide terrorism; for otherwise mentally healthy individuals to commit to schemes that require their own deaths bewilders, even frightens most onlookers. While some subsume this behavior as a special case of general terrorism - meaning that the same explanatory variables for the latter will apply also to the formerthe best available evidence contradicts this interpretative stance. Rather, suicide terrorism in most cases appears to be a sui generis phenomenon needing its own explanation.

The present discussion attempts to provide the missing explanation by employing TMT, which describes how we seek to dispel death anxiety through meanings assigned by cultural symbols. The rise of suicide terrorism can then be accounted for as the outcome of undermining those cultural solutions with competing inferior solutions, in this case consumer capitalism. The TMT perspective promises to encompass a wider range of related phenomena than other competing approaches. While this discussion has focused on one example by providing an account for the differential resort to suicide terrorism, other problems could be similarly explained, such as the lone wolf terrorist.

Suicide terrorism, though, is a complex behavior, and while the available evidence offers initial support for this narrative, it is unlikely to be a complete explanation at the level of particulars. Granting that suicidism springs from existential variables, not all irruptions of these difficulties will be traced back to economic conditions. Some instances will continue to be better explained by political or other social dimensions. In this sense, Pape's analysis that suicide terrorism is primarily about U.S. 
military insertions continues to serve as an intelligible proximate cause. ${ }^{164}$ We get a glimpse of the existence of these alternatives when looking again at Table 1. Israel, for example, cannot be easily described as having experienced an insertion of new and alien capitalist markets. It is therefore unsurprising that despite its recurring experience with suicide attacks, the relationship between START counts for suicide attacks and ITC trade data does not follow the pattern described, as can be seen in Graph 3.

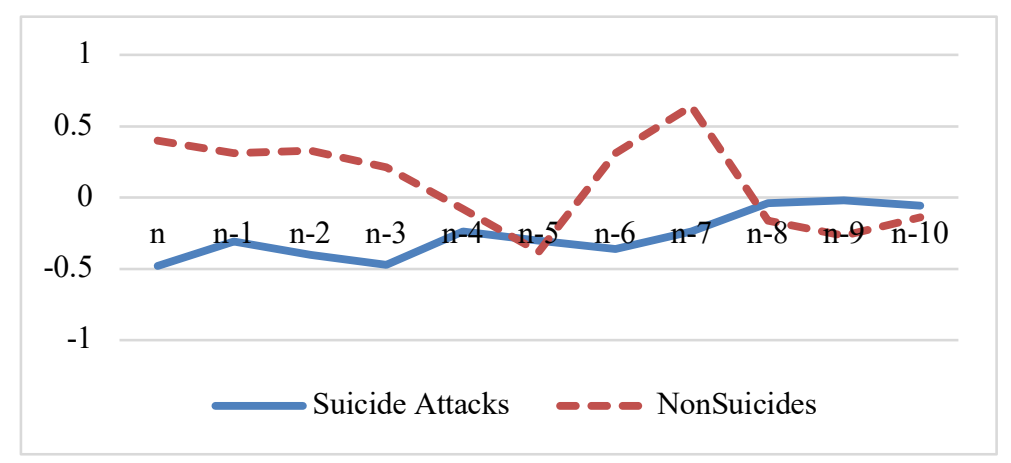

Graph 3: Time-Shifted Imports x Attacks Correlations (Israel)

The need for a different approach such as the one offered here has arisen because the political model also does not fully account for the pattern of suicide incidents. The TMT-grounded model presented here serves as the shared ultimate cause, the preservation of cultural significance-defining institutions, explaining why many would find self-annihilation in defense of the idea of a country (like Palestine) attractive, while not requiring that overt political views are the sine qua non of suicide attacks.

What, then, can be done to respond to the ongoing threat of suicide terrorism attacks? An Obama Department of State official was heavily ridiculed for suggesting that instead of striving to bomb jihadists out of existence, we needed to address the root causes by giving them jobs. ${ }^{165}$ Despite the mockery, this approach makes sense because if money has become the new immortality project, we must offer the means for people

164. See PAPE, supra note 28, at 23; Akhtar Ali Syed, Recent Trends in Suicide Attacks, 8 PAK. J. SOC. CLIN. PSYCH. 73, 85 (2010).

165. Joshua Keating, Conservatives Are Blasting the Obama Administration for Saying Unemployment Causes Terrorism. They're Kind of Right, (Feb. 18, 2015, 1:38 PM), https://slate.com/news-and-politics/2015/02/conservatives-are-blasting-the-obama-administration-for-saying-unemployment-causes-terrorism-theyre-kind-of-right.html. 
to earn income so that they feel that their immortality goals are achievable:

We see the pattern over and over .... [I]f you have prosperity, something that gives them work and opportunity, you address the communities' main vulnerability. If the livelihoods are strong enough, they get a community that is strong enough to band together again when they face a threat. ${ }^{166}$

In an ideal world, the response to suicide terrorism would be to scale back capitalistic incursions into cultural environments where they would be alien and disruptive influences, and to require that marketers conform not to the values of the Western-identified elites, but to those of the ordinary folk. This point is especially true regarding any accompanying advertisements that preach a foreign need for those new items.

Since such a humane policy of globalized economics is unlikely, and in any event the damage has already been done, the most likely outcome is two-fold. First, reports exist of programs to "deradicalize" insurgents when offered the kind of job training and economic support that the theory expects should make a difference. ${ }^{167}$ However, this approach is not easily scalable. While these efforts describe successes, they require individual treatment that is not commensurate with the scope of the problem.

Even without such interventions, the second long-term prospect is that suicide terrorism — or at least the percentage of it that has its roots in economic variables - is likely to gradually age out of the world stage as the culture shock initiated by aggressive capitalistic marketing becomes the "new normal." We are perhaps already seeing the beginning of this development: a recent overview found that while absolute numbers are on the rise, relative to general terrorism, suicide attacks are not increasing, ${ }^{168}$ and may even be noticeably decreasing. ${ }^{169}$ A final look at the pattern of incidents in Table 1 conveys the impression that after the appearance of suicide attacks, incidents reach a peak and then begin to cycle down. For example, while Sri Lanka continues to experience attacks of general terrorism, it has seen no suicide attacks since 2010.

166. GRAEME WOOD, THE WAY OF STRANGERS: ENCOUNTERS WITH THE ISLAMIC STATE 273 (2017) (quoting Justin Richmond).

167. Arie W. Kruglanski et al., Terrorism - a (Self) Love Story: Redirecting the Significance Quest Can End Violence, 68 AM. PSYCH. 559, 559-575 (2013); Arie W. Kruglanski et al., Significance Quest Theory as the Driver of Radicalization Towards Terrorism, in RESILIENCE AND RESOLVE: COMMUNITIES AGAINST TERRORISM 27, 27-28 (Jolene Jerard \& Salim Mohamed Nasir eds., 2015).

168. Dechesne \& Brandt-Law, supra note 25, at 144.

169. Global Terrorism Index 2019: Measuring the Impact of Terrorism, INST. FOR ECON. \& PEACE 64 (2019). 
Given that the world has become more chaotic, theories that ground terrorism and suicide terrorism in political resistance probably would not predict the decline in suicidism we are presently observing. Civilians will no doubt become more dissatisfied as they grow accustomed to the replacement of local values, and will begin to report the levels of mental illness common to Americans. They will, however, grow to view the prevailing mindset as just the way things are, and concentrate on working to find their place within the new order rather than seeking to push it back through violent opposition to restore an earlier system.

Regardless of how the question of suicide attacks develops, we may conclude on the observation that, according to the perspective defended here, the problem arose at least in part because the major powers have been myopic regarding the value of alternative ways of living. The West has appeared to commit itself to the proposition that material advancement is not simply useful, but represents the highest moral good. This belief has led the West to expect that others should share that priority, even when it is unlikely they will all ever be able to enjoy the same benefits. ${ }^{170}$ Yet given that many societies do not share the American view of the independent self, cultural insults that a Westerner might shrug off because of an individualist focus might be devastating to someone with an interdependent concept of self. ${ }^{171}$

There is nothing natural or inevitable in the cultural primacy of material acquisition, and many societies have structured for themselves different symbolic resources to assign meaning and significance to thereby dissolve the death paradox. Global actors need to be more sensitive to how these alternative ways of living are impacted by foreign marketing and economic insertions. These intrusions need to be tied to the existing symbols and lifeways, over time. ${ }^{172}$ As Eric Hoffer observed a generation ago,

[e]ven when a colonial power is wholly philanthropic and its sole aim is to bring prosperity and progress to a ... people, it must do all it can to preserve and reinforce the corporate pattern. It must not concentrate on the individual but inject the

170. Charlotte McDaniel, How Many Earths Do We Need?, BBC News (June 16, 2015), https://www.bbc.com/news/magazine-33133712.

171. Hazel Rose Markus \& Shinobu Kitayama, Culture and the Self: Implications for Cognition, Emotion, and Motivation, 98 PSYCH. REV. 224 (1991).

172. Fathali M. Moghaddam, The Staircase to Terrorism: A Psychological Exploration, AM. PSYCH. 161, 167 (2005). 
innovations and reforms into tribal or communal channels and let the tribe or the community progress as a whole. ${ }^{173}$

If the spread of capitalism is, as some claim, inevitable, we have a duty, or if nothing else a self-serving interest, to assure that this transition occurs in a way that minimizes ideological disruption and thus violent, yet predictable, blowback. 